Pontifícia Universidade Católica

Paula Azevedo Campos

Maternidade e cuidados na primeira infância

Dissertação de Mestrado

Dissertação apresentada como requisito parcial para obtenção do grau de Mestre pelo Programa de PósGraduação em Psicologia do Departamento de Psicologia da PUC-Rio.

Orientadora: Profa. Terezinha Féres-Carneiro

Rio de Janeiro

Março de 2020 


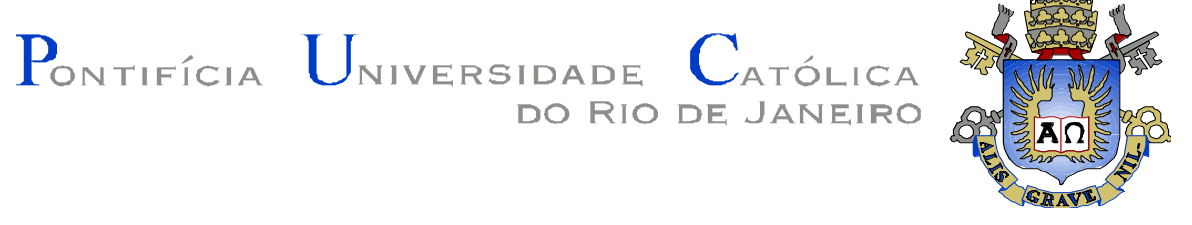

Paula Azevedo Campos

\section{Maternidade e cuidados na primeira infância}

Dissertação apresentada como requisito parcial para obtenção do grau de Mestre pelo Programa de Pós-Graduação em Psicologia (Psicologia Clínica) da PUC-Rio. Aprovada pela Comissão Examinadora abaixo.

Profa. Terezinha Féres-Carneiro Orientadora Departamento de Psicologia - PUC-Rio

Profa. Andrea Seixas Magalhães Departamento de Psicologia - PUC-Rio

Profa. Cristina Ribeiro Teixeira Dantas Membro candidato na Sociedade Psicanalítica do Rio de Janeiro 
Todos os direitos reservados. É proibida a reprodução total ou parcial do trabalho sem a autorização da universidade, da autora e do orientador.

\section{Paula Azevedo Campos}

Graduada em Psicologia pela Universidade Católica do Rio de Janeiro em 2017.

Ficha Catalográfica

Campos, Paula Azevedo

Maternidade e cuidados na primeira infância / Paula Azevedo Campos ; orientadora: Terezinha Féres-Carneiro. - 2020. 79 f. ; $30 \mathrm{~cm}$

Dissertação (mestrado)-Pontifícia Universidade Católica do Rio de Janeiro, Departamento de Psicologia, 2020.

Inclui bibliografia

1. Psicologia - Teses. 2. Maternidade. 3. Puerpério. 4. Cuidados. 5. Profissão. I. Carneiro, Terezinha Féres. II. Pontifícia Universidade Católica do Rio de Janeiro. Departamento de Psicologia. III. Título.

CDD: 150 
Dedico este trabalho a todas as mulheres/mães que, cada uma ao seu modo, deixam no mundo o registro

do seu cuidado. 


\section{Agradecimentos}

À querida orientadora, Terezinha Féres-Carneiro, grande inspiração em minha carreira. pelas valiosas contribuições e pela constante dedicação, que me surpreenderam desde o primeiro contato. Também, por tão generosamente ajudar a construir com carinho a minha história acadêmica, desde a iniciação científica. Minha mais sincera gratidão.

Às professoras que compuseram a banca de exame de projeto, Maria Lucia Rocha Coutinho e Andrea Seixas Magalhães, com quem tive o prazer de conviver no grupo de pesquisa e cujas contribuições foram indispensáveis para a concretização de minha pesquisa. Meu muito obrigada!

A toda equipe de pesquisa da linha de Família e Casal, da PUC-Rio, pela parceria e acolhida necessária para um trabalho mais confiante.

O presente trabalho foi realizado com apoio da Coordenação de Aperfeiçoamento de Pessoal de Nível Superior - Brasil (CAPES) - Código de Financiamento 001.

Agradeço também ao programa de pós-graduação em Psicologia Clínica da Pontifícia Universidade Católica do Rio de Janeiro, e as outras instituições que viabilizaram minha pesquisa.

Aos amigos que, direta ou indiretamente, cooperaram para a realização do meu trabalho. À amiga Anielle Santos, pelo apoio no momento mais difícil da pesquisa. Também aos amigos que construí na psicologia, onde encontrei pessoas que parecem sempre ter estado em minha vida e das quais não consigo me ver longe, em especial à Alessandra Lassen, parceira da vida.

Aos meus queridos pacientes, que me dão o privilégio da sua confiança e compartilham sua existência comigo. Obrigada por me tornarem um ser humano cada dia mais empático. À minha psicóloga, Eliane Seldin, o meu mais profundo agradecimento.

Aos meus amados pai e irmão, que mesmo longe, estão presentes em tudo o que faço.

À minha amada mãe, que me ensinou a colorir o mundo com criatividade $\mathrm{e}$ a ter sempre esperança.

À minha amada irmã, pela ajuda sempre inestimável e por ser tão companheira na minha vida.

Ao meu amor Thiago Correia de Lacerda Braz, que tornou os meus dias melhores e a vida mais leve. 


\section{Resumo}

Azevedo Campos, Paula; Féres-Carneiro, Terezinha. Maternidade e cuidados na primeira infância. Rio de Janeiro, 2020. 79p. Dissertação de Mestrado-Departamento de Psicologia, Pontifícia Universidade católica do Rio de Janeiro.

O presente estudo tem como objetivo investigar as experiências do puerpério e da maternidade exercida na primeira infância. Para tanto, foi realizada uma pesquisa qualitativa, na qual foram entrevistadas dez mulheres das camadas médias da população carioca, atuantes profissionalmente, com idades entre 29 e 37 anos, casadas, legalmente ou não, heterossexuais primíparas e com o filho(a) entre 8 meses e dois anos de idade. Os resultados foram analisados segundo o método de análise de conteúdo na sua vertente categorial. Das narrativas das entrevistadas, emergiram as seguintes categorias de análise: sofrimentos do puerpério; rede de apoio; a história não foi bem assim...; além de mãe: quantos papéis são possíveis?; maternidade e conjugalidade; e quantidade de tempo versus qualidade de tempo. Os resultados serão apresentados em dois artigos. O primeiro pretende investigar a vivência do puerpério pela mulher atualmente. O segundo tem como objetivo discutir como as mulheres vivenciam a maternidade face à conjugalidade e ao exercício da profissão. Os dados apontaram o puerpério como um período idealizado pelas mulheres, mas vivido com sofrimento e instabilidade emocional. Indicaram, ainda, que as mães valorizam estarem presentes nos cuidados dos filhos, e que vivem uma grande tensão na tentativa de conciliar o tempo entre trabalho e família. Foi constatada também a importância da rede de apoio para a mãe e o bebê, e de uma divisão mais igualitária entre mães e pais nos cuidados com o filho e, principalmente, no gerenciamento da casa.

\section{Palavras-chave}

Maternidade; puerpério; cuidados; profissão. 


\section{Abstract}

Azevedo Campos, Paula; Féres-Carneiro, Terezinha (Advisor). Maternity and early childhood care. Rio de Janeiro, 2020. 79p. Dissertação de Mestrado-Departamento de Psicologia, Pontifícia Universidade católica do Rio de Janeiro.

This study aims to investigate how women experience their postpartum and motherhood exercised in early childhood. To this end, a qualitative research was conducted by interviewing ten women from Rio de Janeiro who belong to the middle class, are professionally active, aged between 29 and 37 years, married (formally or otherwise), primiparous heterosexuals, and have a child aged between 8 months and 2 years. The results were analyzed according to the content analysis method and its categorical aspect. From the narratives of the interviewees, the following categories of analysis emerged: postpartum distress; support network; and "It was not quite like that..."; in addition to being a mother: how many roles are possible?; motherhood and conjugality; and amount of time versus quality of time. The results will be presented in two articles. The first intends to investigate the experience of postpartum women today. The second aims to discuss how women experience motherhood in relation to conjugality and the exercise of their occupation. The data pointed the postpartum as a period idealized for women, but lived with distress and emotional instability. It also indicates that mothers value being present in the care of their children and that they experience great tension as they try to share their time between work and family. It was also noted the importance of mother and baby support network, and a more equal division between mothers and fathers in child care and especially in household management.

\section{Keywords}

Motherhood; postpartum period; child-rearing; occupation. 


\section{Sumário}

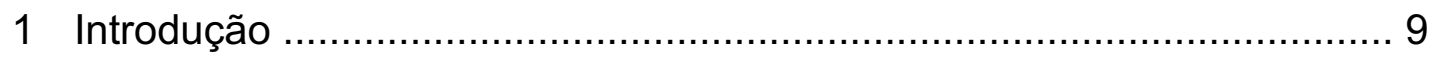

2 Sou mãe: e agora? Vivências do puerpério ..........................................14

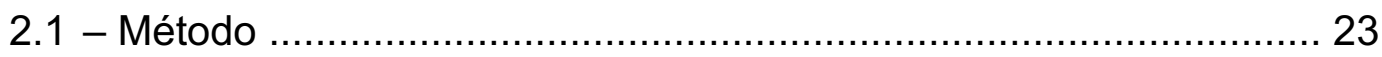

2.2 - Resultados e discussão ................................................... 25

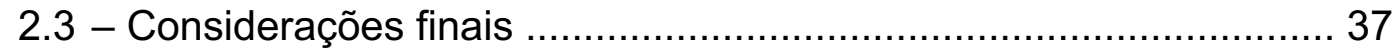

3 Maternidade: Vivências da mulher contemporânea ................................. 39

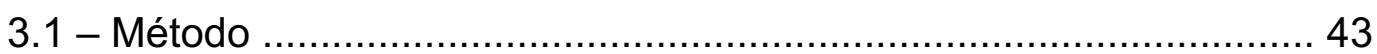

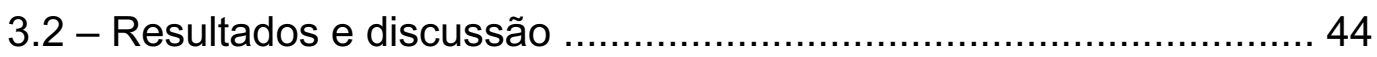

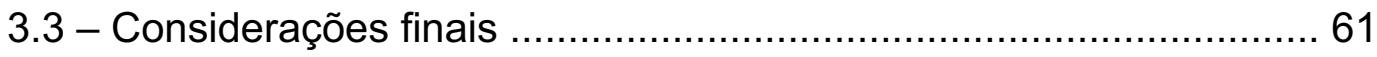

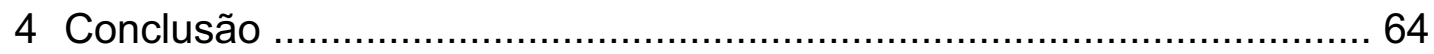

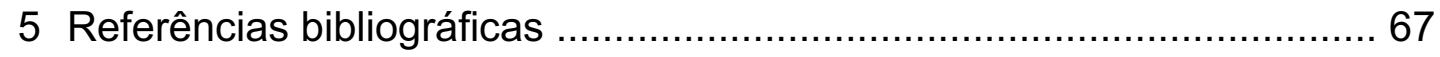

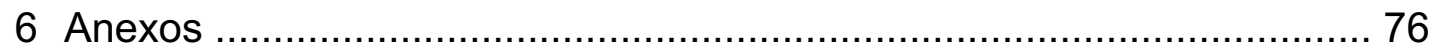




\section{Introdução}

Tornar-se mãe introduz um novo estado de sensações e experiências emocionais que, influenciadas por aspectos psíquicos, fisiológicos, interpessoais e socioculturais, dimensionam a vivência da maternidade e os conflitos que se interpõem na vida da mulher (Stern, 1997). A discussão sobre maternidade e cuidados na primeira infância é antiga e representada pelos mais diversos campos do conhecimento. Desse modo, consideramos que os papéis sociais e as atribuições ligadas a eles devem ser analisados em relação à cultura e ao momento histórico em que estão inseridos (Gradvohl, Osis \& Makuch, 2014). Badinter (2011) aponta que em todas as culturas há um ideal de maternidade a ser seguido e que, invariavelmente, nenhuma mulher escapa de determiná-lo como modelo com o qual se referenciará, isso não quer dizer que irá aceitá-lo, mas que será sempre em relação a ele que medirá sua conduta.

Nesse sentido, compreendemos que as condutas maternas repercutem as crenças e valores que norteiam o contexto em que vivem as mães (Kobarg, Sachetti \& Vieira, 2006), e parecem relacionadas ao fato biológico de serem as mães geradoras e ao papel histórico de cuidadora assumido pela mulher (Falcke \& Wagner, 2000). Todavia, Badinter (1985) faz uma crítica à visão da mulher como geradora e apresenta a maternidade, não como função intrínseca à natureza da mulher, mas construída historicamente e constituída como um mito. A autora debruça-se sobre a história da conduta das mães e encontra uma ampla diversidade de atitudes em relação aos filhos, o que a faz avaliar a experiência de ser mãe como singular à trajetória de cada mulher e à própria história da humanidade. 
Segundo Bowlby (2002), embora o papel da figura principal de apego seja usualmente ocupado pela mãe biológica, pode ser assumido por outras pessoas. De modo resumido, desde que a pessoa que desempenha o papel da figura principal de apego tenha um modo maternal de tratar a criança, isto é, respondendo ativamente a seus sinais e interagindo intensamente com ela, a criança se comportará com o cuidador de maneira semelhante a que outra criança se comportaria com a mãe biológica.

Além disto, Bowlby (1989) e Stern (1997) ressaltam que o cuidado é um aspecto crucial para a saúde emocional do sujeito e que o nascimento do bebê é um momento delicado também para a mãe, o que torna indispensávéis estudos que revelem as condições da mulher para o investimento materno, assim como os arranjos que estão sendo feitos em relação aos cuidados do filho(a), e à promoção da saúde emocional da mulher. Diferentes estudos apontam as dificuldades que as mães enfrentam para se adaptar a esse novo período, em virtude da vulnerabilidade e instabilidade emocional que experienciam com a chegada do bebê. Nessa direção, as pesquisas indicam que, dentro do espectro da depressão pós-parto, não é incomum a vivência do baby blues, pelo contrário, os dados encontrados são de que até $80 \%$ das mulheres passam pelo baby blues no puerpério (Bass \& Bauer, 2018; Kible \& Wells, 2019).

Nesse sentido, a rede de apoio social se mostra fundamental tanto para a mãe quanto para o bebê (Davidson, 2016; Cardoso \& Vivian, 2018; Filha, Ayers, Gama \& Carmo Leal, 2016; Bowlby,1997; Stern, 1997). Em estudo realizado por Rapoport (2003), o apoio foi considerado mais importante em situações de estresse relacionadas ao cansaço da mãe, à necessidade de ter sua vida pautada pelos horários e necessidades do bebê e quando este adoece. Soma-se a isso, o fato de a 
mulher ser atualmente exigida em diferentes direções, o que repercute em dificuldade para manejar seu tempo e em indagações sobre qualidade versus quantidade de tempo investidos no filho(a). Embora não haja uma resposta clara para esta questão, as pesquisas sinalizam a importância dada pelas mães à interação com o filho(a), ainda que isso signifique menos tempo para si e para suas atividades pessoais (Hsin \& Felfe, 2014; Gershuny, 2000; Galinsky, 1999; Booth, ClarkeStewart, Vandell, McCartney \& Owen, 2002).

Ademais, a mulher, mesmo atuando profissionalmente, permanece como a principal responsável pelos cuidados da criança e da casa (Wagner; Predebon; Mosmann \& Verza, 2005), e, com isso, acreditamos que o maior conflito recaia sobre ela. De acordo com dados apresentados pelo IBGE (2017), as mulheres trabalham em afazeres domésticos e no cuidado de pessoas 20,9 horas por semana, enquanto os homens dedicam 10,8 horas do seu tempo, nestas atividades, no mesmo período de tempo. Os índices também demonstram desequilíbrio entre homens e mulheres quando comparados em relação à ocupação; as mulheres que trabalham fora dedicaram 7,8 horas a mais do que os homens nas atividades domésticas.

Esses impasses parecem ficar encobertos, atualmente, nos três discursos que, segundo Badinter (2011), representam olhares de como a maternidade deve ser vivida pelas mulheres: da ecologia; das ciências do comportamento; e de um novo feminismo essencialista. As três perspectivas têm suas origens no fim da década de 1970, onde se inicia uma crítica ao culturalismo - movimento pós-guerra em que se questionam os determinismos naturais e sociais, assim como a condição da mulher na sociedade - e um retorno à natureza.

Com o discurso ecológico, vemos surgir a ideia da mãe ecológica, o grande incentivo ao aleitamento materno e oposição à instrumentalização do parto. Nesse 
contexto, o nascimento do bebê é visto como algo natural. No campo das ciências do comportamento, a pediatria americana também retoma a noção de instinto materno, com base na etologia, da mulher como mamífera e composta de hormônios da maternagem. Desse modo, o laço entre a mãe e o bebê é percebido como algo natural e imediato após o parto, por razões neurobiológicas e químicas, sendo os casos em que isso não ocorre, correspondentes às questões do meio social ou a uma provável patologia da mãe.

Por fim, o feminismo adota uma nova visão e assume a maternidade como vivência essencialmente feminina. Para Badinter (2011), as formas de maternagem são múltiplas e não podem ser contempladas de modo radical. Tais discursos representam uma minoria de mulheres, intelectuais e ativistas, sendo que a grande maioria transita entre recomendações e opiniões que têm como base essas perspectivas, sem, no entanto, se sentir representada por uma única perspectiva. Vêse assim, com o movimento naturalista, acentuar-se o ideal da boa mãe como aquela que naturalmente coloca as demandas do filho(a) acima de qualquer coisa e assume os deveres maternos como naturais.

No entanto, parece muito difícil corresponder ao ideal materno, em um mundo cujas obrigações do trabalho se tornam cada vez maiores. Desse modo, quanto maiores as exigências nos dois sentidos, mais acentuados se tornam os conflitos na vida da mulher. Azevedo e Arrais (2006) apontam que as pressões culturais, inerentes às expectativas da mãe perfeita e idealizada, sob as quais as mulheres exercem a maternidade, associadas à incapacidade de se adequarem a esta visão romanceada, repercutem em sentimentos de ansiedade e de culpa.

No âmbito dessas considerações, realizou-se uma pesquisa qualitativa, com o objetivo de investigar as experiências do puerpério e da maternidade exercida na 
primeira infância. Foram entrevistadas dez mulheres das camadas médias da população carioca, atuantes profissionalmente, com idades entre 29 e 37 anos, casadas, legalmente ou não, heterossexuais primíparas e com o filho(a) entre 8 meses e dois anos de idade. Foi utilizado um roteiro semiestruturado em entrevistas individuais com cada sujeito. A partir dos relatos obtidos emergiram seis categorias de análise: sofrimentos do puerpério; rede de apoio; a história não foi bem assim....; além de mãe: quantos papéis são possíveis?; maternidade e conjugalidade; e quantidade de tempo versus qualidade de tempo. Para fins de apresentação dos resultados, essa dissertação foi elaborada em formato de dois artigos. O primeiro tem como foco central investigar a vivência do puerpério pela mulher atualmente. O segundo estudo tem como objetivo discutir como as mulheres vivenciam a maternidade face à conjugalidade e ao exercício da profissão. 


\section{Sou mãe: e agora? Vivências do puerpério}

Resumo

O presente estudo é parte de uma pesquisa mais ampla sobre maternidade e cuidados na primeira infância, e tem como objetivo investigar como as mulheres vivenciam o puerpério atualmente. Para tanto, foi realizada uma pesquisa qualitativa, na qual foram entrevistadas dez mulheres das camadas médias da população carioca, atuantes profissionalmente, com idades entre 29 e 37 anos, casadas, legalmente ou não, heterossexuais primíparas e com o filho(a) entre 8 meses e dois anos de idade. Os resultados foram analisados segundo o método de análise de conteúdo na sua vertente categorial. Para atingir os objetivos deste estudo serão discutidas as seguintes categorias de análise: sofrimentos do puerpério; rede de apoio; e a história não foi bem assim.... Os resultados apontaram o puerpério como um período idealizado pelas mulheres, mas vivido com sofrimento e instabilidade emocional. Constatamos a importância da rede de apoio para a mãe e o bebê.

Palavras-chave: maternidade; puerpério; baby blues; rede de apoio 
I'm a mother: what now? Postpartum experiences

\section{Abstract}

The present study is part of a broader research on maternity and early childhood care. It aims to investigate how women experience their postpartum period today. To this end, a qualitative research was conducted and ten middle-class women from Rio de Janeiro were interviewed who were professionally active, aged between 29 and 37 years, married (formally or otherwise), primiparous, heterosexual, and who had a child between 8 months and 2 years old. The results were analyzed according to the content analysis method and its categorical aspect. To achieve the goals of this study, we discussed the following analysis categories: postpartum distress; support network; and "It was not quite like that...". The results showed that the postpartum period is idealized by women, who actually experience distress and emotional instability. We highlight the importance of the support network for both mothers and their children.

Keywords: maternity, postpartum period, baby blues, support network 
A gravidez é considerada como um período crítico de transição, biologicamente determinado, capaz de produzir um estado temporário de instabilidade emocional em virtude das mudanças no papel social, na identidade, e das adaptações interpessoais e intrapsíquicas que a mulher precisa fazer. Tal período se estende ao puerpério, que também comporta modificações fisiológicas, assim como mudanças na rotina e no relacionamento familiar (Maldonado, 2013). No pós-parto ocorre uma mudança de foco para o bebê, no entanto, a mãe ainda precisa de cuidado e amparo, devido as ansiedades que este momento desperta na mulher. O baby blues parece estar associado a uma combinação de perdas e adaptações que a puérpera vivencia, como as mudanças no corpo, a experiência com o bebê real e não mais idealizado, e as próprias necessidades que não podem ser atendidas em razão das demandas do bebê (Sarmento \& Letúbal, 2003). Costa (2018) aponta em seus resultados o sofrimento como sendo intrínseco ao puerpério e as mudanças corporais como importante fator dentre os que contribuem para este estado das mães.

A depressão pós-parto pode ser conceituada como um espectro que engloba três categorias: melancolia maternal, conhecida na literatura americana como baby blues; depressão pós-parto; e psicose puerperal. O baby blues ocorre nos primeiros dias após o parto, dura em média entre uma e duas semanas, e acomete de 50 a $80 \%$ das mães (Bass \& Bauer, 2018; Kible \& Wells, 2019). Os sintomas podem incluir ansiedade, choro, apetite diminuído, exaustão, perda de interesse nas atividades habituais, mudanças de humor, tristeza, problemas no sono e preocupação. No entanto, mesmo tendo que lidar com estes sintomas, as mães que apresentam o quadro de baby blues não têm rejeição ao bebê, e o tratamento pode ser feito por meio de apoio emocional (Bass \& Bauer, 2018). A maior conscientização sobre a 
depressão pós-parto pode facilitar a procura por um tratamento adequado e pode ajudar as mulheres a vivenciarem essa condição sem se sentirem anormais em razão de seus sintomas (Strelow et al., 2018).

As causas da DPP envolvem aspectos biológicos, alterações hormonais e estresse emocional, incluindo a privação do sono (Degner, 2017). Os sintomas da depressão pós-parto são mais graves, persistem por mais de duas semanas e, normalmente, requerem intervenção médica. Estes incluem a perturbação do apetite, diminuição de energia, sentimento de desvalia ou culpa excessiva, sentimento de inadequação, rejeição ao bebê e ideação suicida (Sarmento \& Letúbal, 2003). Em sua grande maioria, os sintomas da DPP são desenvolvidos nas quatro primeiras semanas após o parto, mas é possível ocorrerem nos 12 meses subsequentes ao parto (Davidson, 2016). A depressão acomete cerca de 15\% das puérperas e a psicose puerperal cerca de $0,2 \%$ das mulheres (Degner, 2017). Uma revisão sistemática sobre a magnitude da depressão pós-parto no Brasil identificou uma prevalência de cerca de $20 \%$ de DPP em unidades hospitalares terciárias, e 30 a 40\% em unidades básicas de saúde. O estudo aponta os agravos à saúde mental materna na esfera da saúde pública (Lobato, Moraes \& Reichenheim, 2011). Importante salientar que o puerpério também é vivenciado pelo parceiro e que os estados provocados por esse período, tanto na mulher como no homem, se melhor compreendidos e acolhidos por ambos pode ajudar na reorganização e reintegração do casal (Sarmento \& Letúbal, 2003; Degner, 2017).

Já o baby blues ocorre com a maior parte das mulheres e é caracterizado principalmente por instabilidade de humor e choro repentino (Davidson, 2016). Devido à frequência dos casos de baby blues, essa condição é considerada um estado fisiológico possivelmente associado a mudanças biológicas, sendo sua 
intensidade influenciada por fatores psicológicos. A baixa autoestima materna e altos níveis de estresse em relação aos cuidados com o bebê foram identificados como fatores significativos na intensidade do baby blues. O baby blues parece ocorrer devido a uma crescente reação emocional a sentimentos agudos, levando a uma labilidade afetiva e não a um estado de tristeza (M'bailara et al., 2005). O baby blues é descrito por algumas mulheres como uma "montanha-russa emocional". Estudo realizado na Índia revelou que das 64 mães puérperas participantes da pesquisa, $94 \%$ tiveram baby blues e somente $6 \%$ tiveram DPP. Os problemas principais que contribuíram para o desenvolvimento do baby blues foram relativos a problemas financeiros e de sono (Jayasankari, Kirthika, Priya, \& Varghese, 2018).

Resultados de estudo realizado por Schmidt, Vargas, Piccinini e Frizzo (2019) apontam para certa dificuldade das mães em estabelecer interações triádicas em contexto de depressão pós-parto. Em outra pesquisa as mães apresentaram sentimentos de insegurança para assumir os cuidados do recém-nascido e o autocuidado (Strapasson \& Nedel, 2010). O sentimento de não ser capaz de cuidar do bebê, de receber pouco apoio do parceiro, bem como uma reavaliação da relação com sua própria mãe e com o companheiro foram temas que perpassaram os discursos das mães dentro deste contexto (Sousa, Prado \& Piccinini, 2011).

Nenhuma intervenção isolada é apontada como capaz de controlar o desenvolvimento da DPP, no entanto, a rede de apoio é considerada um dos fatores de maior importância para a sua prevenção (da Cunha, Ricken, de Lima, Gil \& Cyrino, 2012; Davidson, 2016; Cardoso \& Vivian, 2018; Maliszewska, Świątkowska-Freund, Bidzan \& Preis, 2016). Outros aspectos citados na literatura que podem prevenir a DPP são: acompanhamento psicológico (Manente\& Rodrigues, 2016; da Cunha et al., 2012); padrões regulares de sono (Davidson, 
2016; Maliszewska et al., 2016); e atividade física, durante a gravidez e no período pós-parto (Kołomańska-Bogucka \& Mazur-Bialy, 2019).

Estudo realizado por Maliszewska et al. (2016) identificou que a insatisfação geral com o relacionamento, alto nível de neuroticismo e introversão, má qualidade de sono, medo do parto e a falta de apoio social foram fatores que aumentaram o risco de desenvolver baby blues. Manente e Rodrigues (2016) verificaram associações entre a DPP e a saúde emocional na gestação; a intenção de retorno ao trabalho; e ao sentimento de falta de ajuda. Podemos afirmar que a presença de uma rede de apoio funciona como um dos fatores de proteção à maternidade. Não somente o apoio instrumental, mas afetivo, fornecendo encorajamento para a que a mulher se sinta autorizada em sua função materna (Filha, Ayers, Gama \& Carmo Leal, 2016).

De acordo com Stern (1997), há inegável existência de aspectos psicobiológicos e, principalmente, hormonais, que predispõem de alguma forma a mãe para exercer a maternagem, no entanto, a amplitude desse fenômeno, denominado por ele de constelação da maternidade, só pode ser contemplada à luz do contexto histórico e cultural em que a mãe está inserida. Desse modo, o autor descreve a constelação da maternidade, e seus temas relacionados, como um fenômeno observado no ocidente, em sociedades pós-industriais, e não algo inato ou atemporal, sendo o aspecto sociocultural preponderante no desenrolar dessas influências psicobiológicas.

Segundo Ariès (1981), a infância, como a vemos hoje, possui raízes históricas e tem seus primeiros vestígios no século XIII. Porém, a sua evolução pode ser percebida, mais claramente, no final do século XVI e no decorrer do século XVII. Na idade média, o sentimento de infância, como um período diferenciado do 
adulto e, portanto, particular, não existia. $\mathrm{O}$ alto índice de mortalidade na primeira infância colocava a criança pequena numa posição desprivilegiada no meio social, como se ela "não contasse". Essa atitude era predominante na idade média, mas ainda deixa seus vestígios nos séculos seguintes.

Em 1780, em Paris, para cada 21 mil crianças que nasciam, mil eram amamentadas pela mãe, outras mil por uma ama que vivia na casa da família, e as outras 19 mil eram cuidadas e amamentadas na casa da ama. Badinter (1985) apresenta tais dados e inverte uma ideia comum entre os historiadores ao sugerir que não era porque as crianças morriam prematuras que as mães se desapegavam delas e as entregavam aos cuidados de uma ama, mas era em razão do desinteresse das mães que tantas crianças morriam. A autora considera a maternidade particular à vivência de cada mulher e aos valores correspondentes ao momento histórico em que vive, e não inerente à sua natureza. Desse modo, afirma que as formas de maternagem são múltiplas e não podem ser contempladas de modo radical, no entanto, ressalta que a grande maioria das mulheres se move entre opiniões que têm como base a noção do amor materno como inato, sem, contudo, se sentirem representadas por essa visão. De acordo com Azevedo e Arrais (2006), embora a experiência materna comporte oscilações, transformações e imperfeições, a visão romanceada de que a mãe não demonstra fragilidades, de que possui uma vocação inata ao sacrifício, associada à incapacidade da mulher de corresponder a este ideal, contribui para perturbações na vivência da maternidade, como é o caso da depressão pós-parto.

Dentre os fatores culturais de influência na constelação da maternidade Stern (1997) destaca: a valorização do bebê, do seu desenvolvimento e bem-estar; a valorização do papel da mãe e a importância dada à sua responsabilidade em 
relação aos cuidados do bebê, mesmo que parte desse cuidado seja transferido a um terceiro; espera-se que o bebê seja desejado e que a mãe o ame; espera-se que haja um ambiente de apoio para que a mãe possa se dedicar ao bebê; e, por fim, observase a falta de um provimento social eficaz, capaz de preparar e dar apoio para que a mãe exerça o papel maternal. O autor chama de constelação da maternidade, a singular organização psíquica da mulher que se inaugura com a chegada do bebê, particularmente, com o nascimento do primeiro filho. Essa nova organização psíquica é variável, podendo durar meses ou anos. Mas, mesmo sendo temporária, é considerada um construto psíquico independente, composto por novos desejos, medos, fantasias, sensibilidades e ações.

Stern (1997) aponta quatro temas principais relacionados à constelação da maternidade. O tema vida-crescimento, em que a mãe se vê diante da situação inédita de manter o seu bebê vivo, proporcionando um crescimento saudável. Isso a fará questionar se é naturalmente dotada para isso, se como animal humano, após conquistar a sobrevivência individual e conseguir reproduzir, será capaz de fazer viver o seu bebê.

O segundo tema, o relacionar-se primário, se refere ao envolvimento emocional da mãe com o bebê, no seu primeiro ano de vida, e engloba a constituição de laços de apego, de proteção e da regulação do bebê. Este tema está relacionado fortemente à cultura, que nem sempre é consonante com as disposições da mãe, o que pode torná-la temerosa sobre sua capacidade de amar, de ser espontânea com o bebê, de relacionar-se com ele a ponto de identificar suas necessidades. Desse modo, podese questionar: será ela vazia, egoísta ou até mesmo deficiente?

O terceiro tema diz respeito à matriz de apoio, tão necessária, em vista da enorme demanda que não somente o filho, mas também a sociedade confere à mãe. 
Essa função foi, tradicionalmente, delegada ao universo feminino, nas figuras das parteiras, enfermeiras, das avós, tias, irmãs e doulas. Os homens não eram incluídos na dinâmica de cuidados do bebê e da mãe e só mais recentemente passaram a ocupar um papel importante nessa função. Assim sendo, para que a mãe possa desempenhar as tarefas de manter vivo o bebê e de propiciar seu desenvolvimento psíquico-afetivo, a matriz de apoio tem dupla função: a de atender suas necessidades vitais, afastando-a temporariamente das obrigações do mundo externo; e de prover apoio psicológico, dando acolhimento, valorizando-a, fazendo com que a ela se sinta apreciada e instruída (Stern, 1997).

O quarto e último tema denominado de reorganização da identidade, diz respeito à transformação na identidade de filha para mãe, ao se tornar genitora e introduzir uma nova geração. Essa reorganização da identidade conduz a uma nova distribuição de tempo e investimentos emocionais. Não é de se admirar que a nova mãe reative modelos positivos e negativos de maternagem, dado o contexto evocativo presente de intensa interação mãe/bebê, que irá convocar os esquemas de interação vivenciados com sua própria mãe. Nessa direção, Stern (1997) apresenta três discursos e preocupações, que permeiam essa reelaboração mental experienciada pela mãe: o discurso da mãe com sua mãe, mais especificamente da relação com a mãe quando criança; o discurso da mãe consigo, particularmente, no seu papel de mãe; e o discurso com o filho. Consonante com esta perspectiva, Bowlby (1997) sugere que existe uma forte relação entre os sentimentos despertados na mulher quando se torna mãe e os sentimentos experienciados por ela quando criança em sua família de origem. Segundo Corrêa e Serralha (2015), os modelos internalizados e vivenciados de mulher e mãe têm influência no desenvolvimento e agravamento da depressão pós-parto. Nesse sentido, o 
nascimento do bebê mostra ser um período crítico também no desenvolvimento da mãe, e que, assim, “também os pais deveriam ser ajudados logo depois que tenham 'nascido"” (Bowlby, 1997, p.37).

Tão importante quanto os estudos que analisam a forma de cuidado dispensada à criança são estudos que dão conta do porquê a mãe adota esse modelo de relação e a influência das suas experiências com seus próprios cuidadores, além do apoio que possui para exercer a maternidade. Segundo Bowlby (1997), é provável que seja universal a ativação do comportamento de apego da mãe de um bebê pequeno, fazendo com que também as mães necessitem ser cuidadas e confortadas nesse momento. Nessa direção, a literatura vem apontando a importância de uma rede de apoio para as mães, o que sugere aumentar a sua responsividade à criança e trazer benefícios à família a curto e longo prazo (Goldstein, Diener \& Mangelsdorf, 1996; Rapoport \& Piccinini, 2006).

Com base em tais considerações, a presente pesquisa, que é parte de um estudo mais amplo sobre maternidade e cuidados na primeira infância, tem como objetivo investigar como as mulheres das camadas médias da população carioca vivenciam o puerpério atualmente.

\subsection{Método}

Foi realizado um estudo de campo exploratório, utilizando uma metodologia qualitativa.

Participantes

Participaram da pesquisa dez mulheres das camadas médias da população, atuantes profissionalmente, com idades entre 29 e 37 anos, casadas, legalmente ou 
não, heterossexuais primíparas, com o filho entre 8 meses e dois anos de idade, e residentes na cidade do Rio de Janeiro.

\section{[INSERIR TABELA 1]}

Instrumentos e procedimentos

Para a obtenção dos dados foi realizada uma entrevista, com roteiro semiestruturado, contemplando os seguintes eixos temáticos: cuidados na primeira infância, dimensões da maternidade e conjugalidade. As participantes foram selecionadas a partir de contatos informais em diferentes redes de sociabilidade da pesquisadora. As entrevistas foram agendadas com antecedência, a partir da disponibilidade das participantes, realizadas pela própria pesquisadora, gravadas em áudio e transcritas integralmente.

Procedimentos éticos

O projeto de pesquisa que deu origem a este estudo foi aprovado pelo Comitê de Ética da universidade onde foi desenvolvido. Todas as participantes assinaram o Termo de Consentimento Livre e Esclarecido, concordando com a utilização dos dados coletados para fins de pesquisa e publicação científica, preservada a identidade das mesmas e de suas famílias.

Análise dos dados

Os dados foram analisados por meio do método de análise de conteúdo, tal como proposto por Bardin (2011), em sua vertente categorial. Do discurso das participantes emergiram várias categorias de análise. Para atingir os objetivos 
propostos neste estudo, serão apresentadas e discutidas as seguintes categorias de análise: sofrimentos do puerpério; rede de apoio; e a história não foi bem assim....

\subsection{Resultados e discussão}

Sofrimentos do puerpério

Tornar-se mãe e dar vida a um bebê é um momento sensível, que implica uma série de transformações. As participantes definem o puerpério como um período de emoções intensas, ressaltando os sofrimentos vivenciados por elas.

(...) Porque a gente deixa de ser quem a gente era assim, e aí é dificil porque tudo muda, o corpo muda, você olha pro espelho aí você vê um quadril mais largo, um peito maior, um tronco mais largo, você tá mais gorda do que você era, suas roupas não cabem mais, isso vem tudo junto, é... aí vem com a insegurança do seu casamento não ser mais o mesmo... Eu no começo, quando eu tive o baby blues, eu perguntava assim: Quando é que eu vou assistir televisão com o meu marido de novo... eu ficava super nervosa com isso porque eu pensava, gente... você fica com medo da sua relação não ser mais a mesma, do seu trabalho não ser mais o mesmo (...) (Mãe 9)

(...) ela depende da gente pra tudo, tudo, tudo, tudo, então vira um fardo no sentido assim, o tempo todo é preenchido com essas atividades que é só pra criança, a gente se esquece por completo e a falta de uma noite de sono inteira, tudo isso estressa demais (...). Parece que a gente toma um caixote e não tá vendo a praia, (...) não consegue ainda visualizar com a cabeça pra fora do mar... (...) eu acho 
que tem muita preocupação, eu sou preocupada demais até hoje, mas é... do novo, o novo causa essa, né, essa... esse medo, eu já sou medrosa por natureza, mas assim quando envolve uma criança, né, nosso filho, eu fiquei assim paralisada (...) eu chorava muito, eu chorei muito, muito, muito, muito... (Mãe 8)

De baby blues eu fiquei umas duas semanas. Fiquei de 15 a 20 dias, assim. Eu chorava por qualquer coisa, qualquer coisa. Era uma exaustão, uma exaustão muito grande, né? (...) eu acho que o que eu mais senti, o que mais tive dificuldade foi a questão do sono, né? (...) Eu lembro de ter sido, assim, bem punk, de eu falar: Cara, em que que eu me meti. Que furada foi essa. Eu achei que era uma furada e é um tabu muito grande você falar que você se arrepende de ser mãe, porque todo mundo: Ah, mas é uma benção, tanta gente queria tá no seu lugar. Aí já vem a culpa, a primeira culpa já tá aí.(...) E. eu acho.. Isso foi no puerpério, né? Que foi uma fase muito conturbada (...). Eu não conseguia, eu não conseguia distinguir as sensações, as emoções, era tudo muito confuso, um tempo eu tava bem, logo depois eu já tava, sabe, triste, e aí era uma angústia muito grande. Então eu tinha uma dificuldade pra.. pra verbalizar isso, não conseguia verbalizar, porque nem eu entendia o que eu tava sentindo, eu só falava: Eu acho que eu to com depressão pós-parto. Aí eu chorava, aí depois eu ria. Era uma coisa, assim, muito louca. E aí 20 dias depois passou, acordei um dia bem... (Mãe 1)

Nossa, os primeiros três meses é um baque, aliás, o primeiro mês é baque, né, pros dois, foi bizarro, (...) eu queria morrer, eu falei: O que que é isso? Eu não tomo banho, eu não como, o bebê chora, não dorme, então eu não durmo, não como e não faço mais nada da minha vida, minha vida é ficar assim... (...) que sensação 
louca! Eu já sabia, já tinha lido sobre o puerpério, tinha lido sobre tudo isso, mas falei, cara, quando eu li sobre o puerpério, falei: Ah, eu não vou ter isso não, isso é besteira, eu sou tranquila, sou super bem resolvida comigo, eu não vou passar por isso não... ai de repente eu: Caraca, eu tô passando por isso! Os hormônios tão aqui, eu to vivendo isso e tá rui, tá difícil... ai ligava pras minhas amigas e falei: Gente, é isso mesmo? Ai todo mundo falava: Calma que passa, calma que vai passar, três meses é o mais cruel, com três meses melhora, com seis meses melhora mais ainda... Aí eu fui vivendo, fui vivendo um dia de cada vez (...) parece que tá todo mundo fazendo alguma coisa legal e você tá ali trancada dentro da sua casa, e como você não dorme é meio torturante, né, porque o primeiro mês você não dorme... (...) e método de tortura é não domir, né, (...) você começa a passar milhões de coisas na sua cabeça, aquelas madrugadas infinitas sem dormir, você fica... dá um tilte na sua cabeça (...). (Mãe 10)

(...) são muitas, muitas variáveis de sentimentos, são muitos sentimentos diferentes e picos de estresse e de relaxamento, de paz, de horror, de pânico, é uma esquizofrenia total... (Mãe 4)

Esse novo estado descrito pelas entrevistadas corrobora o que Stern (1997) nomeou de constelação da maternidade, originada pela chegada do bebê e formada por novas sensações, medos, anseios e fantasias. Nesse sentido, pode-se dizer que a mãe, de fato, reorganiza sua identidade, ao transpor o seu papel de filha para ocupar o papel de mãe e inaugurar uma nova geração. A Mãe 9 expõe seus medos, inseguranças, e sua sensação de deixar de ser quem foi, com as mudanças no corpo, na rotina de trabalho e do casal, também as mães 8 e 10 acentuam os esforços que 
a mãe precisa fazer em direção ao filho para atender suas demandas, redimensionando sua vida. Como foi ressaltado por Stern (1997) e por Maldonado (2013) essas transformações se mostram necessárias para que a mãe possa fazer um novo arranjo dos seus investimentos emocionais, da sua distribuição de energia, de tempo, e de suas atividades. As experiências reveladas pelas entrevistadas como a mudança de foco para o bebê, as mudanças no corpo, e a dificuldade de encontrar espaço para as suas necessidades se alinham à combinação de perdas e adaptações que a puérpera vivencia, apontada por Sarmento e Letúbal (2003) como características do baby blues.

As falas das mães demonstram que, dentre as vivências nas semanas subsequentes ao parto, destacam-se, o choro, a falta de descanso e a instabilidade emocional. Estes dados estão consonantes com a literatura que afirma serem o choro repentino, a instabilidade de humor (M'bailara et al., 2005; Davidson, 2016; Bass \& Bauer, 2018) e má qualidade de sono (Davidson, 2016; Maliszewska et al. 2016; Bass \& Bauer, 2018) os principais sintomas do baby blues. As participantes revelam mudanças repentinas de humor e grande conturbação interna: a mãe 8 diz ter se sentido "tomando um caixote na praia", a mãe 1 declara que em um momento “chorava, aí depois eu ria. Era uma coisa, assim, muito louca”, a mãe 4 alude a uma “esquizofrenia total”, e a mãe 10 a uma "sensação louca". Com efeito, Jayasankari et al. (2018) mostram que o baby blues é referido por algumas mulheres como uma "montanha-russa emocional”. Este estado é descrito na literatura como uma reação emocional a sentimentos intensos, conduzindo a uma labilidade afetiva e não a um estado de tristeza (M'bailara et al., 2005).

Nas falas abaixo as mães revelam sentimentos de incapacidade, preocupação, mas ressaltam que não tiveram rejeição ao filho. 
(...) o puerpério é um momento muito difícil, (...) é difícil, emocionalmente se conectar e ter esses cuidados, né? (...) eu acho que não existem sentimentos conhecidos, palavras que se... tem muito medo, né, de... existe muito medo, porque é um ser muito frágil, como assim eu sou capaz só porque eu carreguei ela na barriga, porque fui eu que fiz... é... muito medo de tá fazendo coisa errada (...). (Mãe 4)

(...) Quando eu converso com pessoas assim mais especializadas, dizem que não foi uma depressão pós-parto porque em nenhum momento eu levei isso pra ela assim, eu não tinha rejeição à ela, eu não tinha raiva dela, nada disso, mas eu tive um baby bluezão assim (risos)... bem... e tinha sempre uma sensação disso assim.. tinha uma sensação de que não era natural, não era pra eu ser mãe, porque aí eu comecei a entrar numa de... Caramba, se minha placenta não alimentou ela o suficiente, depois você não tem leite o suficiente, sabe? De repente não é do meu organismo pra ser mãe (se emociona), entrava nessa nóia, e eu acho que eu sempre tive uma coisa... Ih, to me emocionando! Eu acho que eu sempre tive uma coisa certinha e nota 10 e então me dava uma sensação de tá falhando, de tá errando, de não tá no controle, eu acho que isso foi o mais difícil da maternidade... (Mãe 5)

Eu tive um baby bluezinho assim... uns oito dias só chorava assim, mas eu não negava ela nem nada, eu tinha uma hiper preocupação na verdade, eu achava que ela não tava respirando, eu achava que ela ia morrer, achava que ninguém sabia cuidar dela, só eu, entendeu? (Mãe 9) 
(...) Na primeira semana, depois eu descobri até que existe um termo chamado baby blues, na primeira semana eu chorava e falava: Gente, que que eu fiz da minha vida, tipo, eu não quero mais isso, que que eu vou fazer agora... (...) Acho que o primeiro mês, o primeiro mês. Eu não cheguei a ter depressão, tipo assim, eu cuidava dela, na verdade eu não queria nem que ninguém cuidasse (...). No inicio, obviamente, aquela coisa, até o teu corpo se acostumar à privação do sono, eu tava irritada, fiquei naquele momento de irritabilidade, de querer matar um e não ter motivo pra querer matar um, mas eu queria matar, normal... (...) mas ao mesmo tempo assim, é... eu contemplava muito ela, entendeu? Eu gostava de ficar ali, de ler sobre isso, sabe? Tentar fazer a melhor forma possível, eu falava muito com ela também, né, então assim, eu gostava de cuidar, nunca tive problema de dar banho assim, ai não quero dar banho, ai não quero trocar de fralda... não, muito pelo contrário, sabe? (...)Ai inventaram esse tal de blues baby, né, baby blues, porque na boa, não é baby blues, todo mundo tem isso, raras as mulheres que falam: Não, eu senti aquele amor incondicional desde o primeiro momento... Rara, aí pra você não falar que teve uma depressão pós-parto, e pra justificar esse sentimento que é humano, que todas têm, criaram o baby blues, porque todas passaram, todas passaram assim é... não vou afirmar todas, (...) mas pelo menos minhas amigas todas passaram pelo pensamento de: Caralho, o que que eu fiz da minha vida, fudeu... Todas, sabe, a maioria, ai baby blues, não é isso meu amor, é isso, a maternidade é essa, entendeu? Então assim todas tem o baby blues, a maternidade é isso, tem hora que você se estressa, tem hora que você dorme, você dormiu e teu filho tá lá enfiando o dedo e você fala: Caralho M., psiu, quietinha...(risos), e tudo bem, entendeu? Eu não sou obrigada a ficar lá.. Ai minha filha.. Oh, que lindo, enfiando o dedinho no meu olho... Não tem nada de lindo 
nisso cara, você tá exausta, só que isso poucas mulheres têm coragem de falar porque a sociedade julga a gente, porque a gente tem que ser um exemplo de mãe, entendeu? (Mãe 7)

Como podemos apreender das falas, as entrevistadas não deixaram de cuidar de seus filhos, mesmo diante de sentimentos conflituosos, como os de estar falhando e de não ser natural. As narrativas enfatizam, ao contrário, uma preocupação excessiva com o bebê e estresse emocional. Esses dados vão ao encontro dos resultados apresentados por M'bailara et al. (2005) que evidenciam a baixa autoestima materna e altos níveis de estresse em relação aos cuidados com o bebê como aspectos significativos que contribuem para a intensidade do baby blues. Em outros estudos, as mães também apresentaram sentimentos de incapacidade e insegurança para assumir os cuidados do recém-nascido dentro do contexto de DPP (Strapasson \& Nedel, 2010; Sousa et al., 2011). Stern (1997) insere essas sensações no tema nomeado por ele de vida-crescimento, em que a mãe se vê como responsável por manter o seu bebê vivo, o que a faz questionar se é capaz e naturalmente dotada para isso. Os relatos das nossas participantes confirmam dados da literatura que indicam um alto índice de baby blues (Davidson, 2016), chegando a acometer de 50 a $80 \%$ das mães (Bass \& Bauer, 2018; Kible \& Wells, 2019), o que equivale a reconhecer o sofrimento como intrínseco ao puerpério, como afirma Costa (2018). Devido à frequência dos casos, essa condição é considerada um estado fisiológico, sendo sua intensidade influenciada por aspectos psicológicos (M'bailara et al., 2005). Cabe salientar, retomando dados da pesquisa de Bass e Bauer (2018), que as mulheres não deixam de exercer a maternagem em razão do baby blues e que o recurso para cuidar das mães pode ser o apoio emocional. 
Rede de apoio

O nascimento de um bebê, devido à sua absoluta dependência no início da vida, exige um cuidado e atenção em tempo integral, o que evidencia a importância de uma rede de apoio neste momento. As mães salientam a necessidade de ajuda com o bebê e, principalmente, do apoio emocional da sua própria mãe para que elas também se sintam cuidadas.

É uma rede de apoio, que é fundamental, nunca imaginei que fosse tão fundamental. (...) No hospital você se sente super amparada, você se sente num porto seguro, cheio de enfermeira, qualquer coisa você liga. Quando você vai pra casa, você fala: Agora o couro vai comer... (...) Mas eu tinha minha mãe, meu pai, meu marido foi pra lá, ficou um mês e meio comigo (a participante foi ter o filho nos EUA, onde a sua família de origem vive atualmente). Então, assim, eu tive uma rede de apoio desde o início incrivel. Minha mãe ficou todos os dias comigo até os oito meses do Antônio. (...) Quando o bebê nasce, você precisa da sua mãe, você só quer sua mãe, você não quer mais ninguém, você não quer ver mais ninguém, você não quer nem ver o bebê, você só quer a sua mãe. Assim, eu senti isso.. Mãe, não sei o que fazer, tô perdida.. (...) Aí minha mãe tinha falado: Não, eu vou com você. Ela tá vindo até agora de novo, vai ficar mais quatro meses aqui, porque ela me dá apoio... (Mãe 1)

(...) se não fosse, por exemplo, a minha mãe, minha mãe ficou um mês aqui comigo... eu chorava horrores assim, não de tristeza não, eu chorava até quando tava feliz, eu chorava o tempo inteiro, você falava bom dia comigo eu já tava 
chorando, então é muita emoção junta, misturada... (...) Minha mãe ficou um mês comigo... e assim, foi uma coisa muito legal, porque aquela coisa também... você já leu do texto da mãe da mãe? (...) Que fala que a mãe da mãe é aquela que olha pra pessoa que ninguém mais tá olhando, então eu falo assim que todo mundo tem que ter a sua mãe um tempo logo depois, porque todo mundo só quer saber do bebê e aí você fica lá, largada naquele turbilhão de emoções assim, sofrendo lá sozinha e aí a única pessoa que vai lembrar de dar comida, de botar você pra tomar banho, de fazer um carinho, de te dar um colo é sua mãe, então isso foi muito importante, minha mãe ter ficado aqui foi fundamental, era a única pessoa que eu conseguia... que eu brigava, porque então tipo eu descarregava todo o meu estresse nela e ela tava lá, virava e ela tava lá de novo, entendeu? Então assim foi muito importante... (Mãe 9)

A necessidade de ser apoiada pela própria mãe corrobora pesquisa realizada por Lopes, Prochnow e Piccinini (2010) a qual aponta que, embora a importância do parceiro seja significativa para as mulheres, o destaque maior é dado ao apoio das figuras femininas, especialmente da mãe. Todavia, na contramão desses resultados, outros estudos mostram que as mães mencionam o apoio do companheiro como o mais importante (Dessen \& Braz, 2000; Zanatta, Pereira \& Alves, 2017). A fala da mãe 1 demonstra a sensação de estar perdida e precisar de amparo e orientação; também a mãe 9 relata a necessidade de se sentir cuidada. Estes dados se alinham às postulações de Bowlby (1997) e Stern (1997) que apontam que a rede de apoio é considerada de extrema importância, não somente no auxílio aos cuidados com a criança, mas, principalmente, no acolhimento à mãe, nas suas necessidades de se sentir cuidada, 
valorizada e instruída. Nessa direção, Filha, Ayers, Gama e Carmo Leal (2016) sinalizam que a presença de uma rede apoio é um fator de proteção à maternidade, tanto o apoio instrumental quanto o afetivo, encorajando a mãe para que se sinta autorizada em sua função materna, além de ser considerada um dos fatores de maior importância para a prevenção da DPP (da Cunha et al., 2012; Davidson, 2016; Cardoso \& Vivian, 2018; Maliszewska et al. 2016). Ademais, a rede de apoio indica aumentar a responsividade da mãe à criança e promover benefícios à família (Goldstein et al.,1996; Rapoport \& Piccinini, 2006).

A mãe 1 acrescenta a culpa que sentia por querer ser cuidada em um momento em que deveria estar apta a cuidar.

Ah, eu me sentia muito... eu me sentia super feliz, assim, sabe? Caramba, agora eu sou mãe... Ai que eu percebi a força que eu tinha, porque, dormindo uma hora na noite e, assim, amamentando, cuidando. Eu me sentia super feliz, mas eu também me sentia precisando de cuidado, falava: Cara, eu também quero ser cuidada. Que nem eu to cuidando dele, eu quero que alguém cuide de mim. E eu não conseguia dizer isso, eu ficava... Eu não conseguia dizer isso pra minha mãe... Falar: Mãe, faz isso pra mim? Eu não conseguia, eu chorava, ficava aflita e por mais que eu tivesse essa rede de apoio, eu era muito controladora de... Não, eu que tenho que fazer as coisas do A., ele é meu filho. Eu que tenho que assumir isso, mais ninguém. E aí, era um processo muito grande até pras pessoas falarem: Não, B., deixa eu ficar um pouquinho com ele, vai descansar, vai passear, vai passear uma hora que seja com o R. (marido) e tal, sabe? Vai dar uma volta... Eu, eu ao mesmo tempo que eu me sentia feliz, eu me sentia muito desgastada, porque só eu queria fazer aquilo, né? Eu queria dominar, vamos dizer assim... (...) Porque eu acho que sentia 
culpa, não posso tá me sentindo agora num momento, eu tenho uma criança pra cuidar, como eu quero ser cuidada? Eu acho, eu imagino que eu estivesse sentindo uma culpa (Mãe 1).

Podemos observar na fala acima, a crença de que o cuidado do filho é responsabilidade da mãe, e como esta crença se desdobra em angústias pelo embate entre o que acredita ser o seu papel, ou seja, ser a única cuidadora do filho, e as sensações experienciadas por, contraditoriamente, desejar receber ajuda e cuidado. Como vimos, esse novo contexto que se insere com a chegada do bebê, pode ativar medos na mulher, não só sobre a sua capacidade de permitir e manter uma rede de apoio, mas também sobre a possibilidade de ser julgada e criticada em seu desempenho como mãe (Stern, 1997). Historicamente, a valorização do papel da mãe e a relevância dada à sua responsabilidade em relação aos cuidados do bebê, agrega sentimentos de culpa em relação às exigências sociais do seu papel (Moura \& Araújo, 2004). Assim, a mãe que se considera como única responsável pelos cuidados com o filho, tende a apresentar sentimentos de ansiedade e insatisfação, como ressaltado por Beltrame e Donelli (2012).

A história não foi bem assim...

Nas narrativas a seguir, notam-se um certo desconforto e culpa face ao fato de as mães não terem, imediatamente após o parto, experimentado o sentimento de amor materno.

Foi assim, foi uma relação, né, minha com o Antônio, que a gente foi construindo dia após dia, se conhecendo... e o meu amor foi crescendo aí, não tive aquele amor. 
Falei: Caramba! É o amor da minha vida! Não tive isso. (...) eu não tive aquele amor à primeira vista, e eu senti uma culpa muito grande por isso, falando: Gente, eu não amo esse bebezinho mais que tudo. Eu amo o meu marido mais que ele, eu amo a minha mãe mais do que amo ele e foi, foi um processo até eu entender isso (Mãe 1).

(...) todo mundo fala assim: Ah, porque ser mãe é maravilhoso, ser mãe é a melhor coisa do mundo, sei lá o que...(...) eu romantizei achando que assim, que ela ia nascer de parto normal e que ia vir pro meu colo, e que eu ia olhar pra aquela criança e falar assim: Ah! Aí vinham aquelas florzinhas no meu coração, né, aquela borboletinha no estômago, sei lá o que, e não foi nada disso, não foi nada disso, entendeu? Primeira decepção. A bichinha nasceu, eu falei: Caralho, puta que o pariu, né, (...) eu tava há 26 horas em trabalho de parto (...). Ai tava crente que ia ser aquela coisa assim que eu ia olhar e falar assim: Ah, minha filha, sei lá o que... não foi isso, já me sinto péssima naquele momento, porque eu falei: Gente, e agora? Quero ter outro filho porque eu quero ter esse sentimento, e aí, não tive... Mas mentira, aí você vai conversando com outras mães e nenhuma teve, algumas sim, mas a maioria não, tipo assim, realmente você olha aquela criança e fala: Ah, que bom, tá tudo ali em ordem, todos os dedinhos, todos os pezinhos, nasceu... mas não é aquela coisa assim: Ah! O amor da minha vida! Não é... a gente já acha que... a gente já se sente culpada naquele momento... (...) então alguém podia falar: Fica tranquila, quando nascer o alívio vai ser muito maior do que simplesmente aquele sentimento de amor, entendeu? Tá tudo bem, no primeiro momento você não vai amar o seu bichinho, você só vai ter o sentimento de cuidar e tá ok porque é isso, o amor vai construindo, aí cada dia que você olha, você fala: Ai que coisa 
fofa, aí você vai amando, vai amando, vai amando, esse amor vai existir, fica tranquila... ninguém fala isso, aí a gente se cobra o tempo todo (...). (Mãe 7)

Estes relatos corroboram a tese de Badinter (1985), que analisa o amor materno como um sentimento construído e não inato e atemporal. A partir de uma ampla pesquisa a autora encontra ao longo da história uma multiplicidade de sentidos atribuídos à maternidade e de vivências da mulher no papel de mãe, o que a faz descortinar o que nomeia de "o mito do amor materno". Para a autora o sentimento de amar o filho (a) é adquirido pela convivência e pelos cuidados dispensados que se desenvolvem com o tempo. Nesse sentido, os modos e representações da maternidade têm relação com os mais variados contextos, períodos, e com os desdobramentos da vida de cada mulher, não podendo o amor materno ser uma universalidade, nem associado ao instinto feminino. Nessa direção, Ariès (1981) pontua que a própria noção de infância sofreu alterações ao longo da história, refletindo também em mudanças no modo como os pais se relacionam com seus filhos. Também Stern (1997) ressalta o tema do envolvimento emocional da mãe com o bebê, que ele chama de relacionar-se primário, como fortemente definido pela cultura. Desse modo, quando as disposições da mãe não encontram ressonância no seu meio social, ela pode se sentir fragilizada, defeituosa, não-natural e questionar-se sobre sua capacidade de amar.

\subsection{Considerações finais}

O nascimento do primeiro filho instaura um novo contexto familiar, com novas demandas, o que requer maior apoio. A rede familiar, especialmente a mãe da mãe, foi considerada por nossas participantes fator preponderante para o bem- 
estar e acolhimento materno. Em suas falas, podemos perceber o sofrimento associado a esse momento, em que a mulher se vê diante do conflito de precisar cuidar, enquanto se sente frágil, instável emocionalmente e também precisando de auxílio.

Nesse sentido, confirmamos a necessidade de maior conscientização sobre o espectro da depressão pós-parto e, com isso, a possibilidade de facilitar a procura por um tratamento adequado e contribuir para que as mulheres vivenciem essa condição sem se sentirem anormais em virtude de seus sintomas (Strelow et al., 2018). Para tanto, observamos a importância de esclarecimento, visto que a maior parte das entrevistadas mencionou o quão despreparadas estavam para os sentimentos que as acometeram no puerpério.

Importante ressaltar, ainda, que o puerpério também é vivenciado pelo parceiro (Sarmento \& Letúbal, 2003; Degner, 2017), o que nos leva a considerar a relevância de estudos que investiguem os estados provocados no homem por esse período e os conflitos relacionados ao tema. Nosso objetivo esteve centrado nas questões do puerpério materno, todavia, sabemos da importância de incluir o papel do pai nessa discussão. Sugerimos estudos futuros que aprofundem as questões relativas às interações triádicas, pai, mãe e filho(a), no período do puerpério e as influências destas nos estados emocionais de ambos os membros do casal. 


\section{Maternidade: vivências da mulher contemporânea}

Resumo

O presente estudo é parte de uma pesquisa mais ampla sobre maternidade e cuidados na primeira infância, e tem como objetivo investigar como as mulheres vivenciam a maternidade face à conjugalidade e ao exercício da profissão. Para tanto, foi realizada uma pesquisa qualitativa, na qual foram entrevistadas dez mulheres das camadas médias da população carioca, atuantes profissionalmente, com idades entre 29 e 37 anos, casadas, legalmente ou não, heterossexuais primíparas e com o filho(a) entre 8 meses e dois anos de idade. Os resultados foram analisados segundo o método de análise de conteúdo na sua vertente categorial. Para atingir os objetivos deste estudo serão discutidas as seguintes categorias de análise: além de mãe: quantos papéis são possíveis?; maternidade e conjugalidade; e quantidade de tempo versus qualidade de tempo. Os resultados apontaram que as mães valorizam a sua presença nos cuidados do filho, e que vivem uma grande tensão na tentativa de conciliar seu tempo entre trabalho e família. Constatamos a importância de uma divisão mais igualitária entre mães e pais nos cuidados com o filho e, principalmente, no gerenciamento da casa.

Palavras-chave: Maternidade; conjugalidade; tempo; profissão; cuidado 
Motherhood: experiences of contemporary women

\section{Abstract}

This study is part of a broader research on motherhood and early child-rearing. It aims to investigate how women experience motherhood in relation to conjugality and the exercise of their occupation. To this end, a qualitative research was conducted by interviewing ten women from Rio de Janeiro who belong to the middle class, are professionally active, aged between 29 and 37 years, married (formally or otherwise), primiparous heterosexuals, and have a child aged between 8 months and 2 years. The results were analyzed according to the content analysis method and its categorical aspect. To achieve the goals of this study, the following analysis categories were discussed: In addition to being a mother: how many roles are possible?; motherhood and conjugality; and amount of time versus quality of time. The results showed that mothers value their own presence in child-rearing and that they experience great tension as they try to share their time between work and family. We noted how important it is that mothers and fathers share child-rearing and especially household management in a more balanced way between them.

Keywords: Motherhood; conjugality; time; occupation; child-rearing 
No contexto atual, em que as realizações pessoais e profissionais são fortemente valorizadas (Silva Neves, Ferreira Dias \& Leitão Paravidini, 2013), a pressão social sobre a atuação da mulher tem tido efeitos em sua qualidade de vida. Os sofrimentos decorrentes daí parecem estar associados ao fato de a mulher ser exigida atualmente em diferentes direções, sem, contudo, deixar de ocupar o papel central de cuidadora do lar e dos filhos (Schulte, 2016; Cavalcanti \& Baía, 2017).

Desse modo, para compreender as atitudes maternas é preciso considerar a mãe, adotando o sentido mais frequente - casada e com filhos legítimos -, de modo relativo e tridimensional. Relativo, pois a mãe existe dentro da relação mãe-paifilho e tridimensional porque é também mulher, com seus próprios anseios, fora da relação mãe e esposa. Sendo assim, todo estudo sobre as atitudes maternas deve abranger os outros dois personagens que compõem a tríade familiar. A relação triangular deve ser entendida do ponto de vista psicológico, mas também como um fato social (Badinter, 1985).

Atualmente, há uma grande discussão sobre as mudanças nos papéis de gênero e a importância de o homem encontrar o seu lugar na família. No entanto, estereótipos de gênero ainda encontram lugar nos discursos sociais e alimentam uma dinâmica familiar com características sexistas e patriarcais (Borsa \& Nunes, 2011; Botton, Cúnico, Barcinski, \& Strey, 2015). Assim, evidenciam-se algumas contradições, visto que a sociedade que impõe ao homem uma atitude participativa e cuidadosa com os filhos é a mesma que tende a discriminar, por exemplo, um pai que precisa se ausentar do trabalho para resolver questões escolares do filho (Arruda \& Lima, 2013). Nesse contexto, em que os jovens são criados de modo mais igualitário, há um receio em relação à chegada do filho, uma vez que, com 
este novo estágio do ciclo vital, vem à tona questões relativas às diferenças entre os gêneros (Matos \& Magalhães, 2014).

Diversas pesquisas têm se voltado para as transformações na dinâmica familiar e as repercussões dos seus novos arranjos no desenvolvimento infantil. Dentre as questões mais discutidas na literatura podemos evidenciar as referentes à quantidade e qualidade de tempo investidas nas crianças atualmente. Os estudos sinalizam que as mães que trabalham compensam o tempo gasto fora diminuindo o tempo consigo mesmas e em outras atividades para se dedicar ao filho(a), além de substituírem quantidade de tempo por qualidade de tempo (Hsin \& Felfe, 2014; Gershuny, 2000; Galinsky, 1999; Booth, Clarke-Stewart, Vandell, McCartney \& Owen, 2002). Contrariando o senso comum, os investimentos de tempo, hoje, com as crianças, parecem ser maiores que no passado, não sem um alto custo para as mulheres. A relevância dada a infância também se mostra maior nos dias atuais.

Por volta do século XVIII e, principalmente XIX, a imagem da mulher se torna crescentemente associada à maternidade, quando, tanto valores liberais como o incentivo à natalidade, fazem dos cuidados maternos, um valor essencial para a preservação da criança. As mulheres da classe alta passaram a ocupar a função de nutrir seus filhos e educar. Conforme as suas funções foram aumentando, também foi se intensificando a valorização da mulher que vive para os filhos e para a família. Estas funções trouxeram status à mulher, mas, quando estas não correspondiam às exigências sociais do seu papel, se culpavam como se agissem contrárias à sua natureza (Moura \& Araújo, 2004).

A partir dos anos 1970, com a chegada da pílula contraceptiva, um novo quadro começou a se formar em relação à mulher. Houve, desde então, uma diminuição da fertilidade, um crescente número de mulheres no mercado de 
trabalho, o aumento da idade média da maternidade e a multiplicidade dos modos de vida da mulher. Com isso, a maternidade deixa de ser o único meio de afirmação da mulher e pode ser vivenciada de modo conflituoso. Para alcançar o ideal de uma vida que concilie a conjugalidade, a experiência da maternidade, e a realização profissional, a mulher atual se vê como negociadora de suas múltiplas identidades (Badinter, 2011).

Com base em tais considerações, a presente pesquisa, que é parte de um estudo mais amplo sobre maternidade e cuidados na primeira infância, tem como objetivo investigar como as mulheres das camadas médias da população carioca vivenciam a maternidade face à conjugalidade e ao exercício da profissão.

\subsection{Método}

Foi realizado um estudo de campo exploratório, utilizando uma metodologia qualitativa.

Participantes

Participaram da pesquisa dez mulheres das camadas médias da população, atuantes profissionalmente, com idades entre 29 e 37 anos, casadas, legalmente ou não, heterossexuais primíparas, com o filho entre 8 meses e dois anos de idade, e residentes na cidade do Rio de Janeiro.

\section{[INSERIR TABELA 1]}

Instrumentos e procedimentos

Para a obtenção dos dados foi realizada uma entrevista, com roteiro semiestruturado, contemplando os seguintes eixos temáticos: cuidados na primeira infância, dimensões da maternidade e conjugalidade. As participantes foram 
selecionadas a partir de contatos informais em diferentes redes de sociabilidade da pesquisadora. As entrevistas foram agendadas com antecedência, a partir da disponibilidade das participantes, realizadas pela própria pesquisadora, gravadas em áudio e transcritas integralmente.

Procedimentos éticos

O projeto de pesquisa que deu origem a este estudo foi aprovado pelo Comitê de Ética da universidade onde foi desenvolvido. Todas as participantes assinaram o Termo de Consentimento Livre e Esclarecido, concordando com a utilização dos dados coletados para fins de pesquisa e publicação científica, preservada a identidade das mesmas e de suas famílias.

Análise dos dados

Os dados foram analisados por meio do método de análise de conteúdo, tal como proposto por Bardin (2011), em sua vertente categorial. Do discurso das participantes emergiram várias categorias de análise. Para atingir os objetivos propostos neste estudo, serão apresentadas e discutidas as seguintes categorias de análise: além de mãe: quantos papéis são possíveis?; maternidade e conjugalidade; e quantidade de tempo versus qualidade de tempo.

\subsection{Resultados e discussão}

Além de mãe: quantos papéis são possíveis?

As mães sinalizam a vontade de olhar para si, não só como mães, e apontam os conflitos que se interpõem em suas vidas em razão deste desejo. 
Porque eu acho que muita gente tem medo de falar, né, de ser julgada, né, se você chegar e dizer: Cara, tá um caos, eu adoro o meu filho, mas eu odeio a maternidade... as pessoas ficam assim: Como assim? Então porque que você teve? (Mãe 10).

Eu amo ser mãe, mas eu não gosto de todas as funções maternas, não tem que dar check em todos os negócios, entendeu? (...) Mas é, as pessoas não conseguem enxergar uma mulher onde existe uma mãe. Porque é esse lugar meio sacro, meio intocado, entendeu? Você não pode querer trepar, se maquiar, beber, sair e gostar pra caralho de ser mãe, porque se você gosta disso você não é uma boa mãe... é muito binário assim, sabe? É isso que eu acho. Escreve isso aí (rs). (Mãe 2)

(...) foi dificil abrir mão do meu lado profissional, entendeu? Então assim, era um misto de tipo assim, por exemplo, quando eu voltei a trabalhar, eu fiquei seis meses em casa, eu já não aguentava mais ficar em casa... no dia que eu voltei... ah, me pintei toda, me arrumei, e fiquei uma semana tipo maravilhosa, ai que delicia... Ai, na semana seguinte, eu chorava, chorava, chorava, que não queria mais não estar com a minha filha, né, é muito louco assim, tinha um lado meu que eu não queria abrir mão, ai eu me sentia culpada o tempo todo (...) eu chegava no trabalho chorando, eu saia do trabalho chorando porque eu queria ficar com a minha filha, e que a minha filha tava lá jogada na creche, e que eu ia buscar e já tava tudo apagado, entendeu? Mas ao mesmo tempo eu não queria abrir mão do meu trabalho... Então, foi assim, muito difícil (Mãe 7) 
(...) tem sempre esse conflito, sempre esse conflito, porque eu não quero deixar de ser uma boa mãe, uma mãe presente pra ela, mas a minha parte profissional sente assim (...) eu me sinto às vezes mal de estar bem quando eu to trabalhando, entendeu? Porque eu fico pensando: Gente, eu devia tá com ela, mas eu gosto do que eu faço, sabe, eu gosto muito... (Mãe 9)

Conforme as narrativas das participantes, nota-se a necessidade de conquistarem outros meios de realização que não somente pela maternidade. É o que surge nas falas das mães 2 e 10, ao fazerem uma distinção entre ser mãe, e o prazer que há nesta função, e a realização pela maternidade como único modo de existência feminina. Todavia, as participantes mostram a dificuldade em assumir outros desejos, sem deixar de se sentirem boas mães. Diferentes autores apontam que para entender as crenças maternas e a autoimagem que as mães possuem é preciso compreender o ideário social construído e compartilhado entre seus membros (Gradvohl, Osis \& Makuch, 2014; Kobarg, Sachetti \& Vieira, 2006). Assim, ser "boa mãe", em maior ou menor grau, está relacionado ao quanto a cultura valoriza ou não a maternidade (Badinter, 2011). As narrativas apresentadas se alinham ao estudo de Azevedo e Arrais (2006) o qual aponta que a noção da mãe perfeita e da satisfação irrestrita com a maternidade não foram substituídas na contemporaneidade, mas, ao contrário, associaram-se a novas exigências sociais na vida da mulher, o que produz ainda mais ambivalências além das já comuns à vivência da maternidade. A tentativa de corresponder a esse ideal acaba por favorecer o desenvolvimento de conflitos e sentimentos de inadequação. As falas da maior parte das nossas entrevistadas corroboram estudo realizado por Cavalcanti e Baía (2017) ao sinalizarem que os conflitos das mães vêm acompanhados pelo 
sentimento de culpa e grande desgaste emocional na tentativa de equilibrar suas diferentes identidades. Entretanto, e o que se mostra mais cruel, é que essa tentativa de negociação entre os papéis de mãe e mulher parece nunca ser alcançada permanentemente, como afirma Badinter (2011).

Selecionamos duas falas da Mãe 1 e da Mãe 3: uma em que se mostram críticas ao discurso social de que a mãe é dotada naturalmente para cuidar do filho e, outra, que evidencia como as mães compartilham a mesma crença criticada por elas, fato que se desdobra em ansiedades.

(...) Na maternidade me senti muito sozinha, ainda mais sendo a primeira de minhas amigas, me senti muito desamparada e é um mundo que se abre pra você e nesse mundo as pessoas só querem saber da criança, ninguém quer saber da mãe... a mãe se vira, a mãe é natural, sabe.. é claro que ela vai saber se virar, ela tem um filho pra cuidar, imagina, claro que ela tá com o psicológico dela todo em dia... (Mãe 1)

(...) Acho que o fato de eu também tá longe... Acho que se eu não tivesse trabalhando, tudo mais, acho que eu não seria tão ansiosa. (...) Por eu ser a mãe dele, eu sei exatamente como ele quer que as coisas sejam... Como têm que ser feitas... (...). Eu falo (para o marido): Amor, você tem de entender que ele tem um vínculo ali...ele me ouviu por 9 meses, ficou dentro da minha barriga 9 meses, ouvindo meu coração, ouvindo minha voz...amamentando... (Mãe 1)

A mãe não tem com quem reclamar. Meu filho quando era pequenininho (...) só parava de chorar no meu colo, (...) foi uns três meses assim. Meu marido falava: 
“Eu não posso fazer nada, ele só quer você, ele só para de chorar com você”. Ele só parava de chorar comigo porque... eu não podia fazer nada, eu tinha que resolver o problema, então eu fui sendo sempre o ponto de consolo até que num momento eu era único ponto de consolo porque todo mundo desistia e me dava, porque eu sou uma instância superior, não tem o que fazer, não tem recurso nenhum, ou eu resolvo ou eu resolvo, entendeu? Os pais não se comportam dessa forma, eles sempre acham que podem recorrer à mãe, as mães, entendeu? E acaba que de fato a mãe acaba se tornando a primeira preferência do filho e é um looping, porque... Ah, realmente, ele só para de chorar comigo porque fui eu que sempre fiz ele parar de chorar, então agora ele só para de chorar comigo realmente. (Mãe 3)

Ele adormece comigo e eu boto no bercinho, dorme no bercinho do lado da cama, mas ele prefere de longe dormir comigo. (...). Ele é agarrado com o pai também, mas se eu tiver perto não tem..., mas ele fica muito bem com o pai se eu não tiver, mas parece que ele sabe o que é mãe e pai... (...)a preferência dele disparado sou eu. (Mãe 3)

Tais dados confirmam pesquisa conduzida por Rocha-Coutinho (2005), com mães atuantes no mercado de trabalho, mostrando como as mulheres percebem a maternidade. Esta foi vinculada à natureza feminina, pelo contato visceral que mãe e filho possuem. Depreende-se daí a distinção no modo como a maternidade e paternidade são compreendidas por essas mães. Essas representações atravessam as narrativas das mães, indicando a ambivalência das mesmas em abandonar a ideia de cuidadora principal. Aparece em suas falas uma reivindicação desse lugar de instância superior na vida do filho(a). Não é de se admirar, portanto, como afirma 
Azevedo e Arrais (2006), que o mito da mãe exclusiva, calcado na maternidade como inerente à mulher e ao ciclo evolutivo feminino, insta a mãe em uma posição de destaque, como o ser mais capacitado em relação aos cuidados do filho(a). Esta crença não é vivenciada atualmente sem conflitos, trazendo ansiedades e culpa na vivência da mulher, como ressaltado por Beltrame e Donelli (2012), e RochaCoutinho (2015).

As entrevistadas expõem que a cobrança se dá para além de ser boa mãe. Para elas a mãe de hoje, deverá ser boa mãe, boa profissional e boa esposa, mas se questionam sobre como tornar isso possível.

(...) outro dia eu li um negócio que era: cobram da mulher hoje em dia que ela trabalhe como se não tivesse filho e crie um filho como se não trabalhasse... Então assim, a conta não fecha. Essa é que é a verdade. Então, é essa sensação de rodar pratinho assim, sabe? (Mãe 5)

(...) conseguir conciliar tudo nunca vai dar, ser mãe, ser mulher, ser dona de casa, ser esposa, não dá, (...) alguns pratinhos tem que cair porque não dá pra fazer tudo. (Mãe 10)

Eu não tenho como cumprir todos os critérios de mulher perfeita, superior (...). Não dá pra mim, trabalhar o dia inteiro (...) porque eu tenho que ser independente, entendeu? Acordar às quatro da manhã pra correr na praia, porque eu tenho que voltar pro meu peso, fazer a comida da criança toda orgânica, porque... Na volta eu tenho que passar no hortifrúti, mas eu tenho que chegar cedo pra tá presente na vida do meu filho, levar pra brincar uma hora na área externa, pô, sabe? Ou a 
criança tem que ter duas mães, né, já que a mãe que é responsável pela porra toda, né, ou então o dia tem que ter cinquenta e sete horas, não dá, não dá. (Mãe 3)

A excessiva sobrecarga de tarefas das mães confirma pesquisa realizada por Silva e Oliveira (2014) que mostra relatos semelhantes em que as mulheres enfrentam cobranças em suas funções de mãe, esposa, cuidados com a casa, e demonstram preocupação com o pouco tempo que possuem para dar conta de tudo, não sobrando espaço para cuidar de si e das suas próprias necessidades. $\mathrm{O}$ tempo livre da mulher, fica assim, determinado ao cumprimento de tarefas, intensificando suas ansiedades, preocupações e frustrações, como ressaltado por D’Elia (2014). Nessa direção, Passos e Guedes (2018) apontam que o papel da mulher, sob o ponto de vista econômico, vem sofrendo alterações, especialmente, nos últimos cinquenta anos na sociedade brasileira. A antiga configuração familiar tem sido substituída por um modelo de conciliação, em que a mulher trabalha, além de se manter como responsável pelas questões familiares. Como vimos, no contexto atual, em que a realização pessoal e profissional são valorizadas e direcionam os indivíduos a buscarem satisfazer as suas demandas individuais (Silva Neves; Ferreira Dias \& Leitão Paravidini, 2013), a maternidade e o sofrimento se tornaram fortemente ligados na vivência da mulher. A pressão social é sentida em duas direções, tanto em seu investimento materno quanto em seu engajamento no trabalho; nesse sentido, as mães enfrentam desafios que as colocam numa constante tensão, relacionada ao que precisarão renunciar em suas vidas para exercer essas funções (Schulte, 2016; Cavalcanti \& Baía, 2017).

Uma das soluções encontradas para esse dilema tem sido estender ao máximo o projeto de ser mãe. 
(...) Mas aí vai entrando numa questão do relógio biológico mesmo e também do tempo de relacionamento, começa uma pressão de todo mundo, né e tal, e você vai fazendo aquelas contas... ah, se eu quiser ter dois tem que começar agora, enfim... Todas essas questões... (Mãe 5)

Foi muito difícil, porque assim eu sempre soube que eu queria ser mãe, mas eu nunca tinha coragem porque eu trabalhava muito (...) então eu demorei pra poder tomar coragem, na verdade eu não tomei, meu marido que ficou enchendo o saco (...) ai eu falei: Mas eu to começando agora na equipe e tudo, então vai ser muito difícil... Aí ele falou: Ai, a gente tem idade, tá ficando velho... aquela coisa toda... Eu falei: Ah, então tá bom, vamo deixar... (Mãe 9)

(...) quando a gente pensou em ter filhos, pensou em ter uma filha, já tava na hora, eu já tinha passado dos 30, porque a minha meta era 32, pelo menos aos trinta e dois eu vou ter, aí meu marido perdeu o emprego, aí eu falei: Então eu vou segurar mais um pouquinho, ai segurei 33, 34... aí a gente falou: Chega, porque se a gente for esperando a vida perfeita, não vai ter. Então com $35 \ldots$ então vamos tentar, vamos resolver isso porque senão vai ficar esperando não sei quanto tempo, aí tentamos, ai foi rápido assim, com quatro tentativas a gente engravidou... (Mãe 10)

(...) E aí a gente casou, aí eu continuei estudando, e aí o tempo foi passando, eu já tava com 35 pra 36, meu marido ele toma um medicamento e quando ele quisesse ter filho ele iria ter que fazer um tratamento, e ai o tempo tava 
passando, ele falou: Ó, melhor a gente começar, a gente não sabe quando vai dar certo o tratamento, vamos pelo menos começar... (Mãe 8)

As falas das mães confirmam pesquisas que apontam o adiamento da maternidade (Miranda-Ribeiro, Garcia, \& Faria, 2019; Biffi \& Granato, 2017; Lopes, Dellazzana-Zanon, \& Boeckel, 2014), principalmente entre mulheres mais escolarizadas e com maior renda familiar per capita (Oliveira \& Marcondes, 2014; Oliveira; Vieira; Marcondes, 2015). Esse perfil de mulheres tem mais chance de completar os 30 anos sem ter tido filhos e $1 / 4$ entre 30-34 anos chega a este período também sem filhos (Oliveira \& Marcondes, 2014). Nossos resultados se alinham aos dados encontrados por Bernardi (2018), que indicam que os casais têm priorizado alcançar suas aspirações individuais antes de iniciarem o projeto de ter um filho(a).

\section{Maternidade e conjugalidade}

As diferenças entre as funções relacionadas ao gênero podem ser sentidas, mais evidentemente, com a chegada do filho. As mulheres expressam sua insatisfação por cuidarem sozinhas da organização da casa, mas ponderam o excesso de suas funções argumentando que o marido ajuda em relação aos cuidados com o filho.

O gerenciamento da casa ele não consegue fazer como eu consigo, não consegue, (...) roupa de cama você tem de trocar dia tal, você tem que lembrar que tem que lavar... Então, uma coisa ou outra, claro que eu fico mais sobrecarregada, mas 
em relação ao T., ele acorda de manhã, ele corta fruta, dá o café da manhã, troca o T., dá banho no T., põe o T. pra dormir, eu não posso reclamar... (Mãe 1)

(...) os homens não conseguem entender a nossa carga mental, que quem cuida do organizacional, quem tem que organizar se a fralda tá... se tem fralda, se não tem fralda, se a pomada acabou, se falta lencinho... é sempre a gente, né, a gente que tem que cuidar se tem comida, se tem fruta, se tem legumes, se tem isso, se tem aquilo... Ai, ele até compra, ele até vai na farmácia e compra fralda (...), ele me ajuda nesse sentido(...) e com ela é... 100\% assim, não tem essa coisa assim... os dois dão a janta... trocar a fralda e ver se ela tá assada, ver se ela tá doente... (Mãe 7)

Ele não fica com a parte mental da coisa, porque ele não pensa na comida, ele não pensa na... entendeu? (...) Qual é a organização daquilo, ele não pensa nisso. (...) Se precisar, no perrengue ele faz, mas no geral, no geral, essa parte mental da coisa sou eu mesmo. O resto.... mas fazer ele faz, ele dá banho, ele troca de roupa, ele aspira o nariz... (Mãe 9)

(...) mas o cuidado assim no final de semana ele também ajuda... é ruim falar ajuda, né, porque é dos dois a responsabilidade, mas obviamente eu faço muito mais (risos), não tem nem comparação (...) (Mãe 8)

As falas das participantes confirmam resultados de pesquisas que indicam que o novo pai se mostra mais participativo e envolvido com as questões dos filhos, embora continuidades no modelo tradicional ainda possam ser sentidas. (Rocha- 
Coutinho, 2015; Castoldi, Gonçalves \& Lopes, 2014; Bernardi, 2017; Oliveira \& Silva, 2017). Nossas entrevistadas se queixam, principalmente, por se manterem como gerenciadoras e organizadoras da casa, ficando com a "parte mental", e os homens contribuindo com a execução das tarefas. Desvela-se assim, na narrativa das mães, que, mesmo diante desse novo cenário, em que a divisão sexual do trabalho começa a ganhar contornos menos díspares, indícios de manutenção de um modelo familiar associado aos papéis, com a responsabilidade pela casa sendo atribuída à mulher, e os homens preservando mais seus espaços individuais, o que corrobora estudos desenvolvidos por Castoldi, Gonçalves e Lopes (2014), e Pasinato e Mosmann (2016). O "mas ele ajuda", extraído do discurso das mães, revela, por um lado, o esforço dos homens em exercer mais funções e, por outro, uma valorização de sua participação apoiada em antigos valores familiares. Parece haver, por parte da mulher, uma insatisfação e ambivalência em relação aos dois modelos de família, antigo e novo, uma vez que a representação tradicional não atende às exigências do momento, assim como o modelo atual parece não trazer gratificação. Com efeito, ambos não chegam a ser vivenciados de forma efetiva, pois o antigo, em sua forma original, já sofreu transformações, e o modelo novo não chegou a se estabelecer, de fato, com a consolidação, por exemplo, de novas responsabilidades domésticas e paternas dos homens em consonância com os novos papéis da mulher, como sinalizam Negreiros e Féres-Carneiro (2004), e RochaCoutinho (2015). Cabe ressaltar, que o alto nível de escolaridade dos cônjuges associado ao engajamento do pai nos cuidados do filho(a), como descrito pelas mães, vão ao encontro dos dados da pesquisa conduzida por Wagner, Predebon, Mosmann e Verza (2005) que sinalizam que o aumento da escolaridade dos pais 
parece contribuir para a diminuição da separação existente entre os papéis e funções tradicionalmente assumidos na família.

Quantidade de tempo X qualidade de tempo

As preocupações relativas ao investimento de tempo nas crianças ficam evidenciadas nos questionamentos das mães que trabalham fora.

As pessoas falam muito assim... que qualidade de tempo é mais importante do que a quantidade, né? Acho mais ou menos isso... Eu acho que quantidade também é importante. (Mãe 2)

(...)eu fico muito na dúvida se é qualidade ou quantidade de tempo que é melhor (...) É, porque assim, o tempo que eu estou com ela eu tento estar com um tempo de qualidade pra ela, só pra ela, brincando com ela, tando... só que aos mesmo tempo o meu tempo hoje em dia tem sido muito pequeno, entendeu? (...) eu fico pensando tipo: Será que em algum momento ela vai sentir... mas eu talvez... mas assim, em algum momento isso vai ser ruim pra ela do ponto de vista de eu tá negligenciando ela ou de eu tá... ai é que eu falo: A qualidade é boa, mas talvez a quantidade talvez também tenha que ser (...) eu às vezes eu tenho vontade de parar, né, bastante coisa pra eu poder ficar com ela, mas e depois eu penso que tipo vai faltar coisa pra gente, ai a gente vai ficar mais estressado, ficar mais... isso talvez reflita nela também, então eu fico sempre nesse dilema assim, se eu tenho que diminuir meu trabalho pra poder ter tempo pra ficar com ela ou se não, entendeu? Eu fico nessa dúvida, ainda não consegui chegar a uma conclusão. (Mãe 9) 
As narrativas das participantes explicitam suas indagações sobre o que seria mais importante na criação de seu filho (a), qualidade ou quantidade de tempo. Com efeito, não há na literatura um consenso sobre esta questão. Bernal, Fernández e Peña (2011) apontam que o efeito da quantidade e qualidade de tempo no desenvolvimento socioemocional e cognitivo da criança é mediado significativamente pelas práticas parentais. Pesquisa realizada pelos autores identificou que a qualidade do tempo materno tem efeito positivo significativo tanto no funcionamento cognitivo quanto em aspectos emocionais. O efeito positivo da qualidade de tempo materno no desenvolvimento socioemocional da criança é atribuído ao aumento de responsabilidade, facilidade para exploração e competência social. Foi observado ainda que o efeito da quantidade de tempo no desenvolvimento cognitivo é significativo somente para as crianças com mais de três anos e que a qualidade de tempo materno é mais importante para crianças pequenas.

Estudos variados indicam que o investimento de tempo materno no desenvolvimento da criança é um determinante quantitativamente importante na formação de habilidades cognitivas da criança, no primeiro ano de vida (Del Bono, Francesconi, Kelly \&Sacker, 2016; Baum, 2003; Baydar \& Brooks-Gunn, 1991; Hill, Waldfogel, Brooks-Guin \& Han, 2005). Mas, esses efeitos tendem a diminuir com o tempo (Del Bono et al, 2016) e são parcialmente compensados pelos efeitos positivos do aumento da renda da família (Baum, 2003). É o que aparece na fala da Mãe 9 quando se refere ao estresse que teria, caso parasse de trabalhar, por diminuir seu poder aquisitivo, o que refletiria na criança. Cabe salientar que o estresse relativo ao trabalho afeta negativamente o desenvolvimento comportamental da criança, ao passo que os investimentos em tempo materno só 
têm efeitos significativos na mediação dessas associações negativas, mas não desempenham um papel relevante isoladamente (Felfe \& Hsin, 2012).

Resultados divergentes apontam para a dificuldade de definir as influências do emprego materno no desenvolvimento infantil. $\mathrm{O}$ emprego materno no primeiro ano dos bebês teve efeitos prejudiciais no desenvolvimento comportamental e cognitivo das crianças em pesquisa conduzida por Baydar e Brooks-Gunn (1991), ao passo que McMunn, Kelly, Cable \& Bartley (2012) não encontraram evidências nesta direção. Para Saraceno (2011), não se trata somente de uma questão de quantidade, mas também da qualidade e natureza desse cuidado e o julgamento do que representa qualidade e natureza do cuidado estão relacionadas ao contexto social e geográfico das famílias. Por exemplo, em países em que tanto o trabalho feminino quanto a disponibilidade de centros de cuidado infantil de qualidade são mais difundidos, a ideia de que é um sofrimento para a criança, em idade préescolar, se afastar da mãe é menos acentuada que em países com baixo provimento de cuidados infantis e onde a participação das mães no mercado de trabalho é baixa. Grande parte das mães ressalta a valorização da sua presença, dedicando-se a atividades que envolvam interação e evitando ocupar-se de outras tarefas, ainda que sejam relacionadas aos cuidados do filho.

Ah, eu valorizo da gente tá realmente presente assim, sabe, tá, mas tá mesmo com a criança, (...) eu fico me cobrando um pouco disso, às vezes eu tento entre uma brincadeira e outra já pegar as fraldas pra repor a mochila, pegar a roupa do dia seguinte e assim, e isso eu penso hoje comigo, pô, a hora que eu to com ela é pra tá com ela mesmo, ainda que eu esteja fazendo coisa pra ela, não... Então eu vou sentar pra brincar, vou descer no play, coisas assim, entendeu? (Mãe 8) 
Pois é... é o tempo, eu acho... (...) o tempo disponível, né, a qualidade do tempo e não quantidade (...) eu tenho que me policiar muito pra quando eu to com ela também estar... não ficar com ela as 24horas (...) e fazendo outras coisas e dando aquela atenção assim, né (...) então eu acho que é qualidade do tempo... (Mãe 4)

Eu tive 2 babás com o T., né...Tive a primeira que foi a $S$. (...) Com a $S$. me afetou de uma forma negativa porque eu já não passava tempo com o T. de qualidade, só cuidava dele, assim...de coisas básicas, que ela não ajudava...com a V. não, com a $V$. eu realmente pude, assim, (...) eu preciso que você cuide disso...(...) Ah, roupa dele, comida...questões básicas dele, da casa... (...) pra eu poder focar no que eu queria focar de fato, que é meu filho e o trabalho, e meu marido. (...) eu chego 5 horas, ele vai dormir umas 7 e meia, esse horário é o horário que eu sento aqui, ele ama ler, desde cedo ler pra ele, ele ama música... Então, é sentar com ele, brincar ou tá no parquinho com ele... (Mãe 1)

(...) eu fico muito tempo longe, então pra mim não é interessante deixar ele em casa e sair, eu dou muito valor pros momentos que a gente tem junto, sabe? Oh, sábado é o dia que eu fico sozinha com ele, todo mundo sai, é o melhor dia pra mim, sabe? Só nós dois em casa, vou sozinha com ele no parquinha, às vezes vou sozinha com ele no shopping, às vezes eu fico na varanda brincando com ele sozinha, levo na piscina, mas pra mim é um dia campeão, sabe? (Mãe 3)

Muito tem-se discutido sobre cuidados na primeira infância e a relação que o desenvolvimento emocional e cognitivo infantil tem com questões referentes à 
quantidade e qualidade de tempo investidos nas crianças. No senso comum, os argumentos mais utilizados são de que a tendência nos dias atuais tem sido diminuir o trabalho e o cuidado dos filhos, devido a sobrecarga de demandas com a qual os pais se deparam, ou seja, maiores obrigações e menos tempo para os filhos. Todavia, as narrativas das participantes corroboram estudos que sinalizam que as mães que trabalham fora substituem quantidade de tempo por melhor qualidade de tempo (Booth, Clarke-Stewart, Vandell, McCartney \& Owen, 2002; Hsin e Felfe, 2014). A Mãe 1 demonstra sua preocupação em dedicar seu tempo a atividades que envolvam o filho, e não gastar tempo em afazeres domésticos, para ter um tempo de qualidade juntos. Este resultado corrobora pesquisa conduzida por Bianchi (2000), a qual aponta que, na verdade, o tempo gasto com os filhos parece ter aumentado nas últimas décadas devido a algumas mudanças no comportamento dos pais e em seus usos de tempo como, por exemplo, na redução do número de filhos, e na diminuição de tarefas domésticas comparado a períodos anteriores.

As falas acima estão em consonância com estudo realizado por Hsin e Felfe (2014). Os autores testaram a hipótese de que o emprego materno é prejudicial para o desenvolvimento infantil, principalmente devido à argumentação de que o trabalho das mães tira dos filhos um tempo valioso com elas, e constataram que as mães empregadas compensam o tempo no trabalho diminuindo o tempo em outras atividades. Estudo comparou dois grupos de mães, um grupo em que os filhos passavam 30 ou mais horas por semana em creches $(n=143)$ e um grupo que não usava o cuidado alternativo ( $n=183)$, do nascimento aos seis meses de idade. Os resultados indicaram que o custo em relação ao menor tempo de interação entre a mãe e o bebê que são inseridos nas creches foi consideravelmente menor do que o esperado, bem como a qualidade da interação parece não ter sido afetada pelo tempo 
separados. Essas conclusões sugerem que as mães tentem compensar o tempo em que estão ausentes, aumentando a sua atenção nos finais de semana, principalmente para aquelas que consideravam que a sua separação tinha efeitos sobre o desenvolvimento do filho, dado que é corroborado pela fala da mãe 3 .

Outro sinalizador dessas transformações é a maior inserção dos homens nos cuidados com os filhos. Ainda que, no geral, as mães se vejam como as principais cuidadoras na família, a dedicação dos pais pode ser percebida no discurso das mães que evidenciam a importância dessa participação.

(...)eu acho importante ele ter o tempo dele com ela e é uma responsabilidade que ele fica com ela, tem que levar na creche e tudo o mais... (...) o cuidado, assim, no final de semana ele também ajuda... (Mãe 8)

(...) ele faz muita coisa pra ela, às vezes prepara a janta dela, assim, ele põe a mão na massa totalmente, acho que única coisa que o G. não fez na B mesmo foi realmente dar o peito, porque não tinha como, porque se ele tivesse ele dava, entendeu? Graças a deus o G. é um cara assim que ele... que ele chega muito junto...(Mãe 6)

(...) acho que pode ser considerado como dividido, sim, (...) ele cuida, ele bota pra dormir quando dá, ele dá comida. (...) ontem, por exemplo, eu cheguei oito horas da noite, ele já tinha dado o banho, ele já tinha trocado a roupa, já tinha dado a mamadeira e botado ela pra dormir, ele faz, ele gosta. (Mãe 9) 
(...) ele que leva ela na creche, né? Porque eu já tô trabalhando. E aí ele vai pro parquinho antes pra depois levar na creche e ele vai amarradão, não porque ele tem que ir. (Mãe 2)

Estas falas corroboram pesquisas que apontam para o fato de que os pais se envolvem mais nos cuidados com os filhos hoje que no passado, ampliando seus investimentos de tempo com as crianças, além de compensar a ausência das mães aumentando atividades que possam promover o desenvolvimento dos filhos (Hsin \& Felfe, 2014; Bianchi, 2000; Booth, Clarke-Stewart, Vandell, McCartney \& Owen, 2002). Em estudo realizado por Sayer, Bianchi e Robinson (2004), mães e pais relataram dispender mais tempo em atividades de cuidado dos filhos no final dos anos 1990 do que na década de 1960. Do mesmo modo, Gershuny (2000) evidencia, por meio de diários de uso do tempo de vinte países, que o tempo que os pais passam com seus filhos aumentou da década de 1970 a 2000. Segundo Galinsky (1999), mesmo com o aumento das horas de trabalho, os pais dispensam mais tempo com seus filhos, devido a gastarem menos tempo com eles mesmos. Ainda para o autor, a responsividade é a chave para a qualidade da relação parentofilial, e não o fato de a mãe trabalhar fora de casa.

\subsection{Considerações finais}

A partir do nosso estudo, observamos como perdura no ideal social da boa mãe aquela que coloca as demandas dos filhos acima de qualquer outra coisa, não sobrando espaço para as suas necessidades individuais, como afirma Badinter (2011). Do mesmo modo, analisamos como as crenças que as mães possuem acerca da maternidade também repercutem em dilemas sobre essa questão, sendo 
deflagradas nas narrativas suas angústias e frustrações. Com isso, vemos a mulher viver uma grande tensão em relação ao tempo dedicado ao trabalho e à família, e a conciliação de ambos.

No entanto, o nó que se faz na vida da mulher contemporânea não pode ser analisado sem inseri-la na perspectiva do casal, que vem tentando se adaptar a essas transformações sociais, e lidando com as tensões próprias dessas mudanças. Esperase, com isso que, no bojo dessas transformações, se proponham políticas familiares capazes de tornar o crescimento profissional e a maternidade possíveis de coexistirem na vida da mulher, sem acarretar em tamanhos dilemas e conflitos pessoais. Para tanto, nota-se que a divisão igualitária de tarefas de cuidados dos filhos e da casa é necessária para essa mudança, como afirmam Fiorin, Oliveira e Dias (2014).

Percebemos ainda como a noção de pouco tempo investido nos filhos atualmente se mostra equivocada, visto que os pais têm dispensado mais tempo nos cuidados com os filhos hoje, em comparação com períodos anteriores. Para Carvalho, Cavalcanti, Almeida e Basto (2008), ainda que a desvalorização social do papel de cuidado possa estar associada historicamente ao fato de ser exercido pelas mulheres ou, de a mulher ter sido historicamente desvalorizada por assumir esse papel, a questão não pode ser simplificada nesses termos. De acordo com Passos e Guedes (2018), a sociedade, ao considerar o cuidado como não trabalho, fragiliza o papel assumido pela mulher ao longo da história e a importância deste para a formação dos seres humanos. Desse modo, a entrada da mulher no mercado de trabalho, tornou visível a questão do cuidado e sua relevância para manutenção da vida em sociedade. Esse momento propicia a desconstrução de ideologias de 
gêneros, que mantêm como pano de fundo, no imaginário social, a mulher como responsável exclusiva pelo cuidado na família.

Cabe salientar que as questões discutidas neste artigo foram concernentes às camadas médias da população. Desse modo, sugerimos estudos futuros que direcionem as investigações às camadas baixas da população, em virtude das diferenças históricas e culturais que norteiam cada uma delas. Acreditamos que tais pesquisas contribuirão para uma discussão ampla e aprofundada em relação aos papéis e funções na família contemporânea. 


\section{Conclusão}

A vivência da maternidade nos dias atuais tem se mostrado conflituosa, em decorrência das já mencionadas mudanças intrapsíquicas e interpessoais, associadas aos novos papéis assumidos pela mulher. Neste trabalho, tivemos como objetivo investigar as experiências do puerpério e da maternidade exercida na primeira infância.

No âmbito dessas considerações, analisamos, dentro do espectro da depressão pós-parto, como o baby blues afetou a maior parte das participantes, repercutindo em grande instabilidade emocional e dificuldade de manejar tal volubilidade no período de maior demanda do bebê. Observamos, também, associada à carência de informação sobre estas vivências, como a idealização com este período contribuiu para aumentar o sofrimento na passagem pelo puerpério.

Percebemos, em função das análises, que a visão das participantes de abnegação irrestrita da mãe repercute em culpas, frustrações e sentimentos de inadequação, por não conseguirem corresponder ao ideal da mãe perfeita. Associase a esta crença, as novas exigências que se somaram na vida da mulher, uma vez que é esperado, entre outras funções, que ela atue profissionalmente, ainda que não possua semelhante prestígio no trabalho, comparado ao dos homens. Além disso, essas cobranças são vividas sem que a mulher encontre subsídios, capazes de mantê-la emocionalmente saudável, ao tentar conciliar suas aspirações pessoais e os cuidados do filho(a). Assim, não é de se admirar, que a ambivalência faça parte das experiências subjetivas maternas, contribuindo para tornar conflituosa a chegada do filho(a).

Desse modo, constatamos que, embora progressos possam ser sentidos em direção a um maior engajamento do pai em relação aos cuidados do filho, a divisão 
das funções entre homens e mulheres ainda se mostra desigual, principalmente na administração da casa, o que acentua o estresse e sobrecarga sentidos pela mulher. Outro aspecto importante, evidenciado pelas mães, é a valorização do fato de estarem presentes nos cuidados do filho(a) e o menor tempo investido em atividades pessoais. Em vista da dificuldade em manejar a distribuição de tempo e energia, uma das soluções encontradas tem sido priorizar as conquistas profissionais para, depois, iniciar o projeto de maternidade. Ainda assim, essa resolução parece não trazer o efeito esperado, visto que, para as participantes, mesmo adiando a maternidade, os conflitos não deixaram de existir.

Ademais, não podemos nos furtar de finalizar esse trabalho mencionando a importância da rede de apoio às mães. Além de se sentirem extremamente fragilizadas, ainda enfrentam a dificuldade de permitirem ajuda em um período em que se espera que estejam plenamente aptas a cuidar. Nessa direção, a mãe da mãe foi apontada pelas entrevistadas como figura importante para que pudessem se sentir mais ancoradas ao exercer a maternagem.

Perceber, afinal, esses conflitos e estratégias nas narrativas das participantes é um dos possíveis caminhos para o entendimento da complexa realidade que o ato de ser mãe implica nos dias atuais. Embora esse trabalho não tenha abordado as vivências paternas, foi observado a importância de estudos que investiguem, pela perspectiva dos pais, as experiências relacionadas a este período e o seu novo papel na família contemporânea. Nessa direção, também cabe ressaltar a relevância de estudos que se destinem a outras camadas sociais, particularmente, às camadas baixas da população, que nos ajudem a compor uma visão mais abrangente sobre o tema. 
Assim sendo, por tudo dito anteriormente, confirmamos a necessidade de políticas familiares, por entendermos que, apesar de a mulher se esforçar por adotar um perfil mediador de tantas demandas, é quase inevitável que as condições atuais acabem por aproximar a experiência da maternidade do sofrimento. A partir do nosso esforço em assumir uma estratégia investigativa que privilegiasse um saber interdisciplinar para pesquisar a maternidade e cuidados na primeira infância, consideramos inapropriado a defesa de um único modelo de maternidade. Depreendemos das análises, isto sim, que as mães promovem uma acomodação dos mais variados aspectos para exercer a maternidade e estes estão relacionados a cada mãe em particular, no que pode ampliar a sua própria força e o seu bem-estar geral.

Além do mais, não há, aqui, a pretensão de que o leitor termine a leitura dessa dissertação sem questionamentos. Pelo contrário, acreditamos que uma pesquisa se mostra tão mais fecunda quanto mais numerosas forem as discussões que suscita, advindas da análise. Esperamos, desse modo, obedecendo ao fluxo inerente aos estudos acadêmicos, que as contribuições desta pesquisa sirvam de motivação para futuros debates e reflexões de cunho integrativo e interdisciplinar. 


\section{Referências bibliográficas}

Ariès, P. (1981). História social da criança e da família. $2^{\mathrm{a}}$ ed. Rio de janeiro: LTC.

Arruda, S. L. S.; Lima, M. C. F. (2013). O novo lugar do pai como cuidador da criança. Estudos Interdisciplinares em Psicologia, v. 4, n. 2, p. 201-216.

Azevedo, K. R., \& Arrais, A. D. R. (2006). O mito da mãe exclusiva e seu impacto na depressão pós-parto. Psicologia: reflexão e crítica, 19(2), 269-276.

Bardin, L. (2011). Análise de Conteúdo. Lisboa, Portugal; Edições 70, LTDA.

Baum, C. (2003). Does early maternal employment harm child development? An analysis of the potential benefits of leave taking. Journal of Labor Economics, $21,409-448$.

Badinter, E. (1985). Um amor conquistado: o mito do amor materno. Rio de Janeiro: Nova Fronteira.

Badinter, E. (2011). O conflito: a mulher e a mãe. Rio de Janeiro: Record.

Baydar, N., \& Brooks-Gunn, J. (1991). Effects of maternal employment and child-care arrangements on preschoolers' cognitive and behavioral outcomes. Developmental Psychology, 27, 932-945.

Bass, P., \& Bauer, N. (2018). Parental postpartum depression: More than "baby blues". Contemporary Pediatrics. Vol. 35, No 9.

Beltrame, G. R.; Donelli, T. M. S. (2012). Maternidade e carreira: desafios frente à conciliação de papéis. Aletheia. N. 38-39. P. 206-217.

Bernal, R., Fernández, C., \& Peña, X. (2011). The differential effects of quantity versus the quality of maternal time investments on child development. Unpublished manuscript, Department of Economics, Universidad de los Andes, Bogotá, Colombia. 
Bernardi, D. (2017). Paternidade e cuidado: "novos conceitos", velhos discursos. Psicologia Revista, 26(1), 59-80. doi:https://doi.org/10.23925/2594$\underline{3871.2017 \mathrm{v} 26 \mathrm{i} 1 \mathrm{p} .59-80}$

Bernardi, D. (2018). O adimento do projeto parental na contemporaneidade. MudançasPsicologia da Saúde, 26 (1), 59-64.

Bianchi, S.M. (2000) Maternal employment and time with children: dramatic change or surprising continuity? Demography, 37 (4) (2000), pp. 401-414.

Biffi, M. \& Granato, T. M. M. (2017). Projeto de ter filhos: uma revisão da lite- ratura científica nacional e internacional. Temas em Psicologia, 25 (1), 207-220.

Booth, C. L., Clarke-Stewart, K. A., Vandell, D. L., McCartney, K. and Owen, M. T. (2002), Child-Care Usage and Mother-Infant “Quality Time”. Journal of Marriage and Family, 64: 16-26. doi: $10.1111 / \mathrm{j} .1741-3737.2002 .00016 . \mathrm{x}$

Botton, Andressa, Cúnico, Sabrina Daiana, Barcinski, Mariana, \& Strey, Marlene Neves. (2015). Os papéis parentais nas famílias: analisando aspectos transgeracionais e de gênero. Pensando familias, 19(2), 43-56.

Borsa, J. C., \& Nunes, M. L. T. (2011). Aspectos psicossociais da parentalidade: O papel de homens e mulheres na família nuclear. Psicologia Argumento, 29(64), 31-39.

Bowlby, J. (1997). Formação e rompimento dos laços afetivos. $3^{\mathrm{a}}$ ed. São Paulo: Martins Fontes.

Castoldi, L., Gonçalves, T. R., \& Lopes, R. C. S. (2014). Envolvimento paterno da gestação ao primeiro ano de vida do bebê. Psicologia em Estudo, 19(2), 247-259. Carvalho, A.M.A.; Cavalcanti, V.R.S.; Almeida, M.A.; \& Bastos, A.C.S. (2008). Mulheres e cuidado: bases psicobiológicas ou arbitrariedade cultural?. Paidéia. 2008;18(41):431-444. 
Cardoso, A. C. A., \& Vivian, A. G. (2018). Maternidade e suas vicissitudes: a importância do apoio social no desenvolvimento da díade mãe/ bebê. Diaphora, 17(1), 43.

Corrêa, F. P., \& Serralha, C. A. (2015). A depressão pós-parto e a figura materna: uma análise retrospectiva e contextual. Acta Colombiana de Psicología, São Paulo.

Costa, Aline Oliveira da. Depressão, autoestima e satisfação conjugal no ciclo gravídico puerperal: implicações para a maternidade. (2018). 184 folhas. Dissertação de Maestradp (Psicologia da Saude) - Universidade Metodista de Sao Paulo, São Bernardo do Campo.

Cavalcante, N. C. S. B., Baía, D. C. P. Ser mãe no mundo do trabalho: notas sobre os desafios da reinserção de mulheres no mercado de trabalho após a experiência de maternidade (2017). In: Seminário Internacional Fazendo Gênero, 11., 2017.

da Cunha, A. B., Ricken, J. X., de Lima, P., Gil, S., \& Cyrino, L. A. R. (2012). A importância do acompanhamento psicológico durante a gestação em relação aos aspectos que podem prevenir a depressão pós-parto. Saúde e Pesquisa, 5(3).

Davidson, M. R. (2016). Postpartum Depression. Encyclopedia of Family Studies, 1-4.

Del Bono, E., Francesconi M, Kelly, Y., Sacker, A. (2016). 'Early maternal time investments and early child outcome', Economic Journal, vol.126(596), pp. F96135.

Degner, D. (2017). Differentiating between "baby blues," severe depression, and psychosis. Bmj, 359, j4692.

D'Elia, Tatiana Charpinel Pereira (2014). A vida sem pausas: um estudo sobre a experiência do tempo livre da mulher contemporânea. orientadora: Terezinha Féres-Carneiro. - Tese de doutorado- Pontifícia Universidade Católica do Rio de Janeiro, Departamento de Psicologia. 
de Oliveira, A., \& Silva, R. (2017). Pai contemporâneo: diálogos entre pesquisadores brasileiros no período de 1998 a 2008. Psicologia Argumento,29(66).

Dessen, M.A., \& Braz, M.P. (2000). Rede social de apoio durante transições familiares decorrentes do nascimento de filhos. Psicologia, Teoria e Pesquisa, 16, 221-231.

Falcke, D., \& Wagner, A. (2000). Mães e madrastas: mitos sociais e autoconceito. Estudos de Psicologia, 5(2), 421-441.

Filha, M. M. T., Ayers, S., da Gama, S. G. N., \& do Carmo Leal, M. (2016). Factors associated with postpartum depressive symptomatology in Brazil: the Birth in Brazil National Research Study, 2011/2012. Journal of affective disorders, 194, 159-167.

Fiorin, P. C., Oliveira, C. T., \& Dias, A. C. G. (2014). Percepções de mulheres sobre relação entre trabalho e maternidade. Revista Brasileira de Orientação Profissional, 15(1),25-35.

Felfe C. \& Hsin, A. (2012). Maternal work conditions and child development. Economics of Education Review, 31, 1037-1057.

Felfe C. \& Lalive R. (2014). "Does Early Child Care Help or Hurt Children's Development?'IZA Discussion Paper N. 8484, Institute for the Study of Labor (IZA).

Galinsky E. (1999). Ask the Children: What America's Children Really Think about Working Parents. William Morrow and Company: New York.

Gershuny J. (2000). Changing Times: Work and Leisure in Postindustrial Society. Oxford University Press: Oxford.

Goldstein, L.H.; Diener, M.L.; \& Mangelsdorf S.C. (1996). Maternal characteristics and social support across the transition to motherhood: associations with maternal behavior. J Fam Psychol. ;10(1):60-71. 
Gradvohl, S. M. O.; Osis, M. J. D.; Makuch, M. Y. (2014). Maternidade e formas de maternagem desde a idade média à atualidade. Pensando famílias, Porto Alegre, v. 18, n.1, p. 55-62, jun.

Hill, J., Waldfogel, J., Brooks-Gunn, J., \& Han, W. (2005). Maternal employment and child development: A fresh look using newer methods. Developmental Psychology, 41,833-850.

Instituto Brasileiro de Geografia e Estatística (IBGE). Disponível em https://biblioteca.ibge.gov.br/visualizacao/livros/liv101551_informativo.pdf >Acessado em 16 de dezembro de 2019.

Jayasankari, P. P. M. R. S., Kirthika, A. K. I. T., Priya, E. M. N. M. S., \& Varghese, R. S. R. S. E. (2018). A Study to Explore the Factors Contributing to the Development of Postpartum Blues among Postnatal Mothers at Pondicherry Institute of Medical Sciences, Puducherry. International Journal of Advances in Nursing Management, 6(4), 309-312.

Kibler, N., \& Wells, P. (2019). Beyond the Baby Blues. Cross-Cultural Perspective on Perinatal Mental Health.

Kobarg, A. P., Sachetti, V. A., \& Vieira, M. L. (2006). Valores e crenças parentais: reflexões teóricas. Journal of Human Growth and Development, 16(2), 96-102.

Kołomańska-Bogucka, D., \& Mazur-Bialy, A. I. (2019). Physical Activity and the Occurrence of Postnatal Depression-A Systematic Review. Medicina, 55(9), 560. Langaro, Fabíola, \& Pretto, Zuleica. (2015). Experiências de parentalidade como fatores geradores de sofrimento em mulheres. Fractal: Revista de Psicologia, 27(2), 130138. https://dx.doi.org/10.1590/1984-0292/453

Lobato, G., Moraes, C. L. \& Reichenheim, M. E. (2011). Magnitude da depressão pósparto no Brasil: uma revisão sistemática. Rev. Bras. Saúde Matern. Infant. Recife. 
Lopes, Manuela Nunes, Dellazzana-Zanon, Letícia Lovato, \& Boeckel, Mariana Gonçalves. (2014). A multiplicidade de papéis da mulher contemporânea e a maternidade tardia. Temas em Psicologia, 22(4), $\quad$ 917928. https://dx.doi.org/10.9788/TP2014.4-18

Lopes, R. D. C. S., Prochnow, L. P., \& Piccinini, C. A. (2010). A relação da mãe com suas figuras de apoio femininas e os sentimentos em relação à maternidade. Psicologia em estudo. Maringá. Vol. 15, n. 2 (abr.jun. 2010), p. 295304.

Moura, S. M. S. R. de, \& Araújo, M. de F. (2004). A maternidade na história e a história dos cuidados maternos. Psicologia: ciência e profissão, v. 24, n. 1, p. 44-55.

Maldonado, M. T. (2013). Psicologia da gravidez. Editora Jaguatirica Digital.

Maliszewska, K., Świątkowska-Freund, M., Bidzan, M., \& Preis, K. (2016). Relationship, social support, and personality as psychosocial determinants of the risk for postpartum blues. Ginekologia Polska, 87(6), 442-447.

Manente, M.V., \& Rodrigues, O. M. P. R. (2016). Maternidade e Trabalho: Associação entre Depressão Pós-parto, Apoio Social e Satisfação Conjugal. Pensando familias, 20(1), 99-111.

Matos, M. G. de; Magalhães, A. S. (2014). Tornar-se pais: sobre a expectativa de jovens adultos. Pensando famílias, v. 18, n. 1, p. 78-91.

M'baïlara, K., Swendsen, J., Glatigny-Dallay, E., Dallay, D., Roux, D., Sutter, A. L., ... \& Henry, C. (2005). Baby blues: characterization and influence of psycho-social factors. L'Encephale, 31(3), 331-336.

Miranda-Ribeiro, Adriana, Garcia, Ricardo Alexandrino, \& Faria, Tereza Cristina de Azevedo Bernardes. (2019). Baixa fecundidade e adiamento do primeiro filho no 
Brasil. Revista Brasileira de Estudos de População, 36, e 0080. Epub September 30, 2019.https://dx.doi.org/10.20947/s0102-3098a0080

Negreiros, T. C. de G. M.; Féres-Carneiro, T. (2004). Masculino e feminino na família contemporânea. Estudos e pesquisas em psicologia, v. 4, n. 1, p. 34-47.

Oliveira, M. C. F. A. Marcondes, G. Maternidade precoce x tardia: mudança de padrão ou heterogeneidade? (2014). In: Encontro Nacional de Estudos Populacionais, 19., 2014, São Pedro, SP. Anais... Belo Horizonte, MG: ABEP.

Oliveira, M. C. F. A; Vieira, J. M.; Marcondes, G. S. Cinquenta anos de relações de gênero e geração no Brasil: mudanças e permanências. (2015). In: Arretche, M. (Org.). Trajetórias das desigualdades: como o Brasil mudou nos últimos 50 anos. São Paulo, SP: Editora UNESP; CEM, 2015.

Pasinato, L. \& Mosmann, C. P. (2016). Transição para a parentalidade e a coparentalidade: Casais que os filhos ingressaram na escola ao término da licençamaternidade. Avances en Psicología Latino-Americana, 34(1), 129-142. doi:10.12804/apl34.1.2016.09

Passos, L.; Guedes, D.R. (2018). Participação feminina no mercado de trabalho e a crise de cuidados da modernidade: conexões diversas. Planejamento e Políticas Públicas (IPEA), n.50.

Rapoport, A. (2003). Da gestação ao primeiro ano de vida do bebê: Apoio social e ingresso na creche.

Rapoport, A., \& Piccinini, C. A. (2006). Apoio social e experiência da maternidade. Revista Brasileira de Crescimento e Desenvolvimento Humano, 16 (1), 85-96.

Rocha-Coutinho, M. L. (2005). Variações sobre um antigo tema: a maternidade para mulheres com uma carreira profissional bem-sucedida. Em Féres-Carneiro, T. 
(Org.). Família e casal: efeitos da contemporaneidade (pp. 122-137). Rio de Janeiro: Ed. PUC-Rio.

Rocha-Coutinho, M.L. (2015). Investimento da Mulher no mercado de trabalho: repercussões na família e nas relações de gênero. Em Féres-Carneiro, T. (Org.). Família e casal: parentalidade e filiação em diferentes contextos (pp. 103-117). Rio de Janeiro: Ed. PUC-Rio.

Sayer, L. C., Bianchi, S. M., \& Robinson, J. P. (2004). Are parents investing less in children? Trends in mothers' and fathers' time with children. American Journal of Sociology, 110, 1-43.

Saraceno, C. (2011). Childcare needs and childcare policies: A multidimensional issue. 59(1), 78.doi.org/10.1177/0011392110385971

Sarmento, R.; Letúbal, M. S. V. (2003). Abordagem psicológica em obstetrícia: aspectos emocionais da gravidez, parto e puerpério. Rev. Ciências Médicas. Campinas, 2003.

Schmidt, B., Vargas, V. D., Piccinini, C. A., \& Frizzo, G. B. (2019). Coparentalidade no contexto de depressão pós-parto: um estudo qualitativo. PsicoUSF. Bragança Paulista, SP. Vol. 24, n. 1 (jan./mar. 2019), p. 403-430.

Silva, Ângela Cândido da; Oliveira, Leticia Horn. (2014). Conciliando a realização pessoal, o trabalho e a família: um estudo com mulheres do interior do Rio Grande do Sul Revista Psicologia em Foco, v. 6, n. 8, p. 3-21, dez. 14.

Silva Neves, A.; Ferreira Dias, A. S.; Leitão Paravidini, J. L. (2013). A psicodinâmica conjugal e a contemporaneidade. Psicologia Clínica, v. 25, n. 2.

Sousa, D. D., Prado, L. C., \& Piccinini, C. A. (2011). Representações acerca da maternidade no contexto da depressão pós-parto. Psicologia: Reflexão e Crítica. Porto Alegre. 
Stern, D. N. (1997) A constelação da maternidade. Porto Alegre: Artes Médicas. (Original publicado em 1995)

Strapasson, M. R.; Nedel, M. N. B. (2010). Puerpério imediato: desvendando o significado da maternidade. Rev Gaúcha Enfermermagem. Porto Alegre (RS) 2010 set;31(3):521-8.

Strelow, B., Fellows, N., Fink, S. R., O'Laughlin, D. J., Radke, G., Stevens, J., \& Tweedy, J. M. (2018). Postpartum depression in older women. Journal of the American Academy of PAs, 31(3), 15-18.

Schulte, A. A. (2016). Maternidade contemporânea como sofrimento social em blogs brasileiros. Dissertação de Mestrado- Centro de Ciências da Vida, Programa de Pós-Graduação em Psicologia, Pontifícia Universidade Católica de Campinas, Campinas.

Wagner, A.; Predebon, J.; Mosmann, C. \& Verza, F. (2005). Compartilhar tarefas? Papéis e funções de pai e mãe na família contemporânea. Psicologia: teoria e pesquisa, v. 21, n. 2, p. 181-186.

Zanatta, E., Pereira, C. R. R., \& Alves, A. P. (2017). A experiência da maternidade pela primeira vez: as mudanças vivenciadas no tornar-se mãe. Revista Pesquisas $e$ Práticas Psicossociais, 12(3), 16. 


\section{$6 \quad$ Anexos}

\section{Anexo 1}
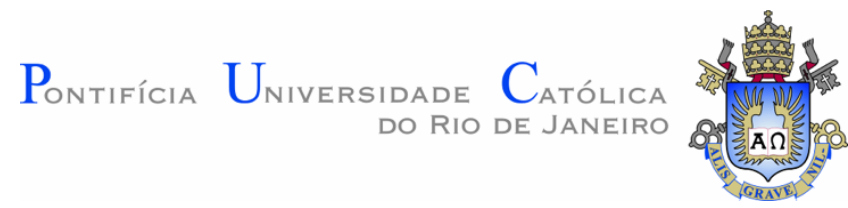

Termo de Consentimento Livre e Esclarecido (TCLE)

Nome do projeto de pesquisa de doutorado: Maternidade e cuidados na primeira infância

Nome da pesquisadora responsável: Paula Azevedo Campos

Email: paulacamposrt@gmail.com; cel: (21) 99540-6920

Orientadora: Profa. Dra. Terezinha Féres-Carneiro

Email: teferca@puc-rio.br; cel: (21) 9911-10180

Comitê de Ética em Pesquisa da PUC-Rio (CEPq-PUC-Rio) Tel.: (021) 3527 -1618

Com esta pesquisa pretende-se investigar a terceirização do cuidado na primeira infância a partir da percepção de mães. A justificativa desta pesquisa se deve ao fato de que os resultados obtidos poderão trazer subsídios relevantes às mães, pais e aos cuidadores alternativos da criança na primeira infância.

Você está sendo convidado(a) a participar desta pesquisa, realizada a partir de uma entrevista, gravada em áudio, pela própria pesquisadora, e, posteriormente, transcrita. A entrevista foi agendada em local sugerido previamente por você e o tempo de duração é de aproximadamente cinquenta minutos. Todas as informações têm caráter confidencial, mantendo-se em sigilo a sua identidade. Após o término desta investigação, as gravações das entrevistas serão apagadas. As transcrições ficarão armazenadas em local sigiloso, sem identificação, em caixas arquivos, por um período de cinco anos sob a responsabilidade da pesquisadora, sua orientadora e da instituição de ensino PUC-Rio.

A sua participação é voluntária, estando você livre para fazer as perguntas que julgar necessárias, recusar-se a responder qualquer pergunta que lhe possa causar desconforto e interromper a entrevista quando assim desejar, sem qualquer constrangimento ou penalização. A pesquisa não tem custo, nem qualquer benefício financeiro ou gratificação decorrente da sua participação. 


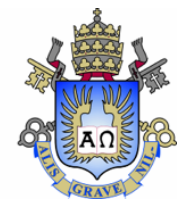

Considera-se que os riscos pela sua participação são mínimos, no entanto, caso haja algum desconforto psicológico durante a entrevista, a entrevistadora estará preparada para o manejo da situação e, se for o caso, para interromper o procedimento e, até mesmo, para sugerir o encaminhamento para um atendimento psicológico.

Ao participar desta pesquisa, você estará contribuindo para o incremento do conhecimento científico sobre cuidados na primeira infância, maternidade e terceirização.

Aparentemente, você não terá nenhum benefício direto. No entanto, esperamos converter os resultados desse trabalho em ações benéficas para toda a população. Além disso, ao participar da entrevista, você terá oportunidade de refletir sobre as questões levantadas e como isso afeta a sua vida, bem como receber um retorno com os resultados da pesquisa, se assim desejar, fazendo contato com a pesquisadora por e-mail ou telefone.

Em caso de dúvidas, você poderá entrar em contato com a pesquisadora responsável ou com o Comitê de Ética em Pesquisa da Pontifícia Universidade Católica do Rio de Janeiro (CEPq-PUC-Rio), no endereço Rua Marquês de São Vicente, 225, Rio de Janeiro - RJ, número de telefone: (021) 3527-1618.

Após esses esclarecimentos, solicitamos o seu consentimento de forma livre para participar desta pesquisa. O Termo de Consentimento Livre e Esclarecido é assinado em duas vias, sendo uma entregue ao participante e, a outra, ao(à) pesquisador(a). Assinando este termo, você está autorizando a utilização das informações prestadas, em ensino, pesquisa e publicação, sendo preservada sua identidade e a dos membros da sua família.

Fui informado(a) sobre o estudo acima referido e compreendi seus objetivos. Tive a oportunidade de fazer perguntas e todas as minhas dúvidas foram esclarecidas. Estou assinando voluntariamente este termo, o que indica que concordo com minha participação nesta pesquisa. 
Assinatura da pesquisadora

Assinatura do(a) entrevistado(a)

Rio de Janeiro,

\section{Anexo 2}

\section{Roteiro semiestruturado para entrevista}

\section{Cuidado materno na primeira infância}

Como foi pra você tornar-se mãe do João?

Como foram os primeiros cuidados?

Como você se sentiu cuidando dele?

E você, como se sentiu cuidada na sua infância?

Quais aspectos você considera mais importantes no cuidado com seu filho?

O que você valoriza na relação de vocês?

\section{Dimensões da maternidade}

Como você se vê como mãe?

O que você considera ser boa mãe?

Como foi a sua preparação para a chegada do João?

Você vivencia algum tipo de pressão em relação à maternidade?

Como você e seu marido lidam em relação aos cuidados do seu fillho? 


\section{Terceirização do cuidado}

E hoje, o que te levou a buscar ajuda no cuidado com seu filho?

O que te levou a escolher esse tipo de ajuda?

Como essa ajuda afeta você? (como mãe e mulher)

De que modo você acha que isso repercute na sua família?

\section{Anexo 3}

TABELA 1

Dados das participantes, filhos(as) e seus cônjuges

\begin{tabular}{|c|c|c|c|c|c|c|}
\hline & Idade & Profissão & $\begin{array}{l}\text { Sexo } \\
\text { do } \\
\text { bebê }\end{array}$ & $\begin{array}{c}\text { Idade } \\
\text { do bebê }\end{array}$ & $\begin{array}{l}\text { Idade do } \\
\text { marido }\end{array}$ & $\begin{array}{l}\text { Profissão do } \\
\text { marido }\end{array}$ \\
\hline Mãe 1 & 29 & Arquiteta & $\mathrm{M}$ & $1 \mathrm{a}$ e $4 \mathrm{~m}$ & 34 & Designer \\
\hline Mãe 2 & 37 & Jornalista & $\mathrm{F}$ & $\begin{array}{l}1 \mathrm{a} \mathrm{e} \\
10 \mathrm{~m}\end{array}$ & 38 & Jornalista \\
\hline Mãe 3 & 33 & $\begin{array}{l}\text { Servidora } \\
\text { pública }\end{array}$ & $\mathrm{M}$ & $1 \mathrm{a}$ e $7 \mathrm{~m}$ & 33 & Empresário \\
\hline Mãe 4 & 36 & $\begin{array}{l}\text { Produtora de } \\
\text { teatro }\end{array}$ & $\mathrm{F}$ & $1 \mathrm{a} e 1 \mathrm{~m}$ & 42 & Autônomo \\
\hline Mãe 5 & 34 & Atriz & $\mathrm{F}$ & 2 anos & 34 & Músico \\
\hline Mãe 6 & 30 & Pedagoga & $\mathrm{F}$ & 2 anos & 32 & Empresário \\
\hline Mãe 7 & 37 & Gerente de ti & $\mathrm{F}$ & $1 \mathrm{a}$ e $5 \mathrm{~m}$ & 47 & Diretor de TI \\
\hline Mãe 8 & 37 & $\begin{array}{l}\text { Servidora } \\
\text { pública }\end{array}$ & $\mathrm{F}$ & $1 \mathrm{a} \mathrm{e} 7 \mathrm{~m}$ & 37 & $\begin{array}{l}\text { Analista de } \\
\text { sistemas }\end{array}$ \\
\hline Mãe 9 & 35 & Médica & $\mathrm{F}$ & $10 \mathrm{~m}$ & 36 & Cirurgião \\
\hline Mãe10 & 36 & Publicitária & $\mathrm{F}$ & $8 \mathrm{~m}$ & 34 & $\begin{array}{l}\text { Gestor de } \\
\text { projetos }\end{array}$ \\
\hline
\end{tabular}

Notas: Idades em anos; $\mathrm{a}=$ anos; $\mathrm{m}=$ meses; $\mathrm{M}=$ masculino; $\mathrm{F}=$ feminino. 